Review article

\title{
Assessment of tsunami hazard to the U.S. Atlantic margin
}

\author{
U.S. ten Brink ${ }^{\text {a, } *}$, J.D. Chaytor ${ }^{\text {a }}$, E.L. Geist ${ }^{\mathrm{b}}$, D.S. Brothers ${ }^{\mathrm{a}, 1}$, B.D. Andrews ${ }^{\mathrm{a}}$ \\ a U.S. Geological Survey, 384 Woods Hole Rd., Woods Hole, MA 02543, USA \\ b U.S. Geological Survey, 345 Middlefield Rd., Menlo Park, CA 94025, USA
}

\section{A R T I C L E I N F O}

Article history:

Received 23 May 2013

Received in revised form 19 February 2014

Accepted 22 February 2014

Available online 22 March 2014

Communicated by: D.J.W. Piper

\section{Keywords:}

submarine landslides

meteo-tsunami

earthquakes and landslides

probabilistic hazard assessment

\begin{abstract}
A B S T R A C T
Tsunami hazard is a very low-probability, but potentially high-risk natural hazard, posing unique challenges to scientists and policy makers trying to mitigate its impacts. These challenges are illustrated in this assessment of tsunami hazard to the U.S. Atlantic margin. Seismic activity along the U.S. Atlantic margin in general is low, and confirmed paleo-tsunami deposits have not yet been found, suggesting a very low rate of hazard. However, the devastating 1929 Grand Banks tsunami along the Atlantic margin of Canada shows that these events continue to occur. Densely populated areas, extensive industrial and port facilities, and the presence of ten nuclear power plants along the coast, make this region highly vulnerable to flooding by tsunamis and therefore even lowprobability events need to be evaluated.

We can presently draw several tentative conclusions regarding tsunami hazard to the U.S. Atlantic coast. Landslide tsunamis likely constitute the biggest tsunami hazard to the coast. Only a small number of landslides have so far been dated and they are generally older than 10,000 years. The geographical distribution of landslides along the margin is expected to be uneven and to depend on the distribution of seismic activity along the margin and on the geographical distribution of Pleistocene sediment. We do not see evidence that gas hydrate dissociation contributes to the generation of landslides along the U.S. Atlantic margin. Analysis of landslide statistics along the fluvial and glacial portions of the margin indicate that most of the landslides are translational, were probably initiated by seismic acceleration, and failed as aggregate slope failures. How tsunamis are generated from aggregate landslides remains however, unclear. Estimates of the recurrence interval of earthquakes along the continental slope may provide maximum estimates for the recurrence interval of landslide along the margin. Tsunamis caused by atmospheric disturbances and by coastal earthquakes may be more frequent than those generated by landslides, but their amplitudes are probably smaller. Among the possible far-field earthquake sources, only earthquakes located within the Gulf of Cadiz or west of the Tore-Madeira Rise are likely to affect the U.S. coast. It is questionable whether earthquakes on the Puerto Rico Trench are capable of producing a large enough tsunami that will affect the U.S. Atlantic coast. More information is needed to evaluate the seismic potential of the northern Cuba fold-and-thrust belt. The hazard from a volcano flank collapse in the Canary Islands is likely smaller than originally stated, and there is not enough information to evaluate the magnitude and frequency of flank collapse from the Azores Islands. Both deterministic and probabilistic methods to evaluate the tsunami hazard from the margin are available for application to the Atlantic margin, but their implementation requires more information than is currently available.
\end{abstract}

Published by Elsevier B.V.

\section{Introduction}

The U.S. Atlantic margin is well suited for the study of lowprobability high-risk tsunami events. The margin is vast $(2500 \mathrm{~km}$ long) and includes a variety of morphological features, sediment types and depositional environments, allowing us to investigate salient parameters that are relevant to hazard assessment. Tsunamis generated by submarine landslide are a significant component of the tsunami

\footnotetext{
* Corresponding author.

E-mail address: utenbrink@usgs.gov (U.S. ten Brink).

${ }^{1}$ Now at U.S. Geological Survey, 400 Natural Bridges Dr., Santa Cruz, CA 95060, USA.
}

hazard to the U.S. Atlantic margin. The first and largest part of this review article describes recent work aimed at understanding submarine landslides, their temporal and spatial distributions along the U.S. Atlantic margin and their relationships to earthquakes, in an effort to quantify their probability of occurrence. This focus stems from the observation of numerous submarine landslide scars along the Atlantic margin and the 1929 Grand Banks landslide tsunami, the only known major tsunami to cause significant damage to locations along the Atlantic coast of North America (Fine et al., 2005). The second part of the article reviews the state-of-knowledge of other sources that have the potential to generate trans-Atlantic or local tsunamis. These include earthquake-generated tsunami sources from the Azores-Gibraltar plate 
boundary, the Puerto Rico Trench, and the northern Cuba fold-andthrust belt, volcanic flank collapse and large landslides in the eastern Atlantic Ocean, and local earthquake and meteo-tsunamis (tsunamis caused by atmospheric pressure disturbances). The third part of the paper reviews recent developments in deterministic and probabilistic approaches to assessing tsunami hazard. The discussion raises several fundamental questions regarding the assessment of landslide tsunamis along the U.S. Atlantic margin.

\section{Tsunami hazard from local landslide sources}

\subsection{The U.S. Atlantic Margin E' characteristics of submarine landslides}

\subsubsection{Physiography of the U.S. Atlantic margin}

The Atlantic margin of the U.S. extends from the Straits of Florida in the south to Georges Bank in the north. The margin continues northeastward offshore Nova Scotia and Newfoundland in Canada. The morphology of the modern margin reflects the results of processes that began when North America and Africa began rifting apart more than 200 million years (Klitgord et al., 1988). Four major basins were formed during that time: the Blake Plateau Basin, the Carolina Trough, the Baltimore Canyon Trough, and the Georges Bank Basin (Klitgord and Behrendt, 1979). These basins coincide with four zones, which from south to north, are influenced by carbonate, salt, fluvial, and glacial processes and exhibit large along-margin variability in sediment supply. From Florida to South Carolina, carbonate production has dominated and modern terrestrial sediment input is low (Dillon et al., 1985), particularly off Florida. This region is centered on the Blake Plateau Basin. Offshore North Carolina, the margin contains salt diapirs sourced from deeply buried Mesozoic rift sediments (Dillon et al., 1982). This region is centered on the Carolina Trough. Between Cape Hatteras and New England, the margin has been dominated by fluvial siliciclastic sediment deposition since the Early Miocene that has buried a deeper and once extensive carbonate reef system (Poag, 1991). Eocene chalk is exposed along stretches of the slope (Poag, 1992). This region is centered on the Baltimore Canyon Trough. Offshore New England, the modern margin reflects glaciogenic processes, which provided abundant sediment from large terrestrial rivers (e.g., Hudson River) that drained extensive glacial landscapes. At the time of the Last Glacial Maximum (LGM), the Wisconsin ice sheet reached part way across the continental shelf of New England and to the shelf edge along the Scotian margin of Canada (Schlee, 1973) (Fig. 1). Mesozoic-Neogene age carbonate and siliciclastic rocks are exposed in some New England canyons (Ryan et al., 1978)(Fig. 1). This region is centered on the Georges Bank Basin.

Examination of the Georges Bank-Southern New England-Hudson Apron margin (Fig. 1) reveals more subtle morphological variations, which are likely governed by the earlier sedimentary history of the margin (Brothers et al., 2013a). The steep Mesozoic reef bank beneath Georges Bank margin appears to have had a profound influence on the evolution and modern-day steepness of the slope, whereas Early Cenozoic stratigraphic packages along the upper and middle slope of Southern New England and the Hudson Apron had gentle, sigmoidal forms that are nearly maintained today (Brothers et al., 2013a).

From Cape Hatteras northward, the shelf slopes gently $\left(<0.5^{\circ}\right)$ to water depths of 100 to $200 \mathrm{~m}$ where a significant change in gradient marks the shelf/slope break (inset in Fig. 1). The continental slope, an area affected primarily by downslope and less frequently by along slope transport and deposition, can be separated into an upper slope and lower slope with the transition between them occurring at a major change in gradient which generally occurs between 1800 and $2000 \mathrm{~m}$. The lower slope has been labeled in many publications as "upper rise" based solely on the morphology. This lower slope region, however, contains landslides and large channels more typical of slope processes (sediment transport), albeit on lower gradient surfaces (e.g., Danforth and Schwab, 1990). The transition from the lower slope to the continental rise (where deposition is dominant) occurs between 4000 and $4500 \mathrm{~m}$.

The carbonate zone has a significantly different across-margin character than the other zones (inset in Fig. 1). South of Cape Hatteras, the continental shelf edge occurs at shallower depths of approximately 80-100 m and steps down via a short steep ramp to the Blake Plateau at $\sim 800$ to $1200 \mathrm{~m}$. The Blake Escarpment and Blake Outer Ridge are the primary morphologic features of the margin. North of the Blake Outer Ridge, the upper/lower slope transition occurs between 2800 and $3000 \mathrm{~m}$, and the transition to primarily depositional processes occurs at approximately $5000 \mathrm{~m}$. South of the Blake Outer Ridge, the Blake Escarpment descends to abyssal depths abruptly at $~ 5000 \mathrm{~m}$ (Inset in Fig. 1).

\subsubsection{Local landslide sources}

Submarine landslides along the U.S. Atlantic margin have been described and analyzed in a number of local (e.g., Embley, 1982; Cashman and Popenoe, 1985; O'Leary, 1986; Prior et al., 1986; Locat et al., 2010, 2013; Chaytor et al., 2012a; Mulder et al., 2012) and regional (Booth and O'Leary, 1991; Booth et al., 1993; Twichell et al., 2009) studies. Past compilations of landslides along the U.S. Atlantic margin utilized a variety of geophysical imaging techniques, beginning with single-channel airgun and sparker seismic reflection profiles (Embley and Jacobi, 1977), to GLORIA sidescan backscatter and early lowresolution swath bathymetry (Booth et al., 1993), and higherresolution but incomplete swath bathymetry coverage of the margin (Chaytor et al., 2007; Twichell et al., 2009). Based on the recent compilation of high-resolution mapping data (Andrews et al., 2013 and references/sources within), landslides and related features along the margin fall into 3 types: Type 1: a landslide 'complex' with a clearly-coupled source/evacuation and deposit areas, Type 2: a landslide 'zone', where a deposition zone either does not exist next to the source/ evacuation zone, or if one is present, it cannot be related to a specific source, and Type 3: mass transport deposits (MTD) with no associated source/evacuation zone.

There are only five well-defined landslide complexes of Type 1 along the U.S. Atlantic margin: the Munson-Nygren-Retriever, Veatch Canyon, Currituck (Albemarle), Cape Lookout, and Cape Fear landslides (marked 1 to 5 in Fig. 1). These previously known landslide complexes are well mapped from early studies (e.g., Embley, 1982; Cashman and Popenoe, 1985; O'Leary, 1986; Prior et al., 1986; Chaytor et al., 2012a), and occur within the various geologic zones with the exception of the carbonate zone. The combined source and deposit areas of these landslide complexes each exceed $3000 \mathrm{~km}^{2}$, and except for the Veatch Canyon landslide, the volume of material evacuated from each is greater than $100 \mathrm{~km}^{3}$. Given their size, these landslide complexes are considered the primary benchmarks for the analysis of submarine-landslidegenerated tsunamis initiated along the U.S. Atlantic margin (e.g., Geist et al., 2009a).

We identified, or redefined, previously identified landslide zones of Type 2 (Chaytor et al., 2009, 2012a; ten Brink et al., 2012) using new multibeam bathymetry (Andrews et al., 2013) and high-resolution seismic data along the margin north of Cape Fear slide (Figs. 2, 3). Headwalls and multiple failure scars, which may overlap or be morphologically connected, are pervasive along the southern New England, Hudson Apron-New Jersey slope, and Baltimore Canyon parts of the margin, but no associated depositional lobes or mass transport deposits (MTD) have been identified (e.g., Fig. 2). The bulk of these landslide zones are confined to the upper slope and along canyon walls, but they are also found along the lower slope where they lie adjacent to mass transport deposits (MTD) emplaced by multiple landslide events. Most of the Type 1 and Type 2 landslides occur in unlithified sediments. The exceptions are landslides identified in lithified Eocene rock exposed along the upper slope off New Jersey (Figs. 1 and 3) and Eocene and 


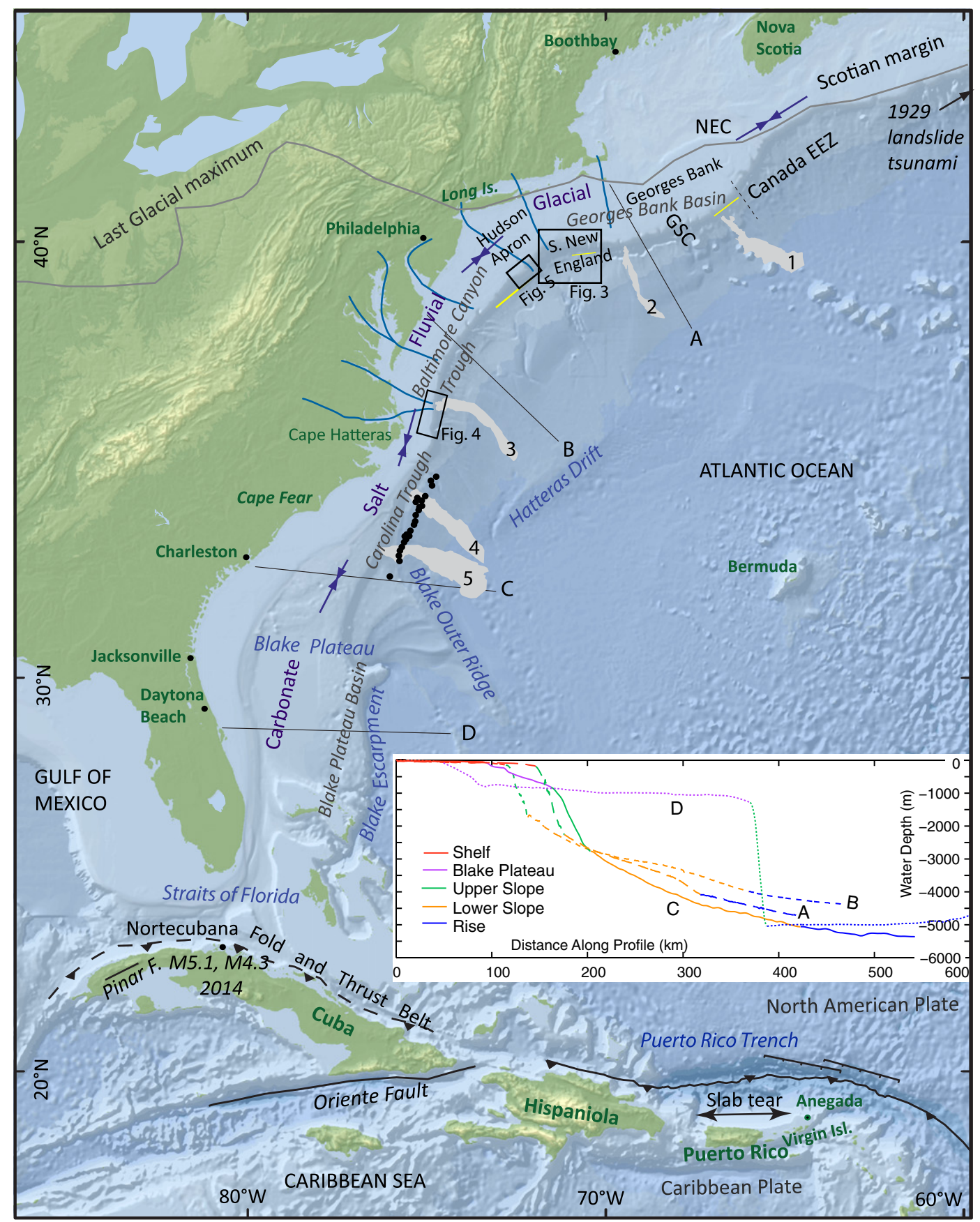

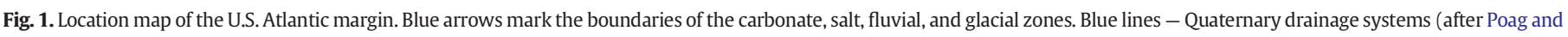

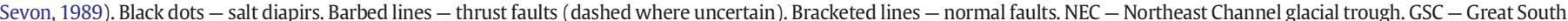

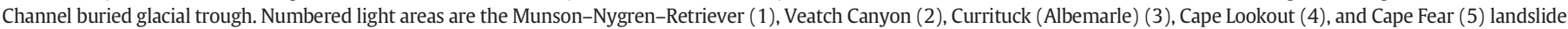

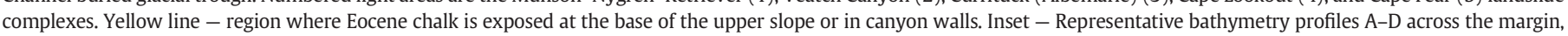
marked by thin lines on map. Colors represent margin components (shelf, upper slope, lower slope, rise and Blake Plateau) used in this paper.

Mesozoic through Neogene carbonate and silciclastic rocks in some of the New England canyons.

MTDs from landslides (debrites) and turbidity currents (turbidites), not connected to specific landslide sources (Type 3 ) are widespread across the continental slope and out to the abyssal plain. Some of these MTD are voluminous (e.g., Elmore et al., 1979), but are currently excluded from our potential tsunami source evaluation due to our limited understanding of their areal extent, deposition pathways, connection to upper slope and canyon processes, age, and postdepositional reworking.

\subsection{Conditions that contribute to slope failures}

High seafloor gradient, rapid accumulation of thick sedimentary deposits, pore-fluid overpressure, weak layers, over-steepening of the slope, and external sources of horizontal acceleration (earthquakes and bottom stress) are conditions most commonly associated with submarine landslides (Hampton et al., 1996; Harbitz et al., 2013 and references therein). Previous studies on the U.S. Atlantic margin suggested that regional slope gradient does not necessarily correlate with landslide occurrence (e.g., Twichell et al., 2009). However, the regional 


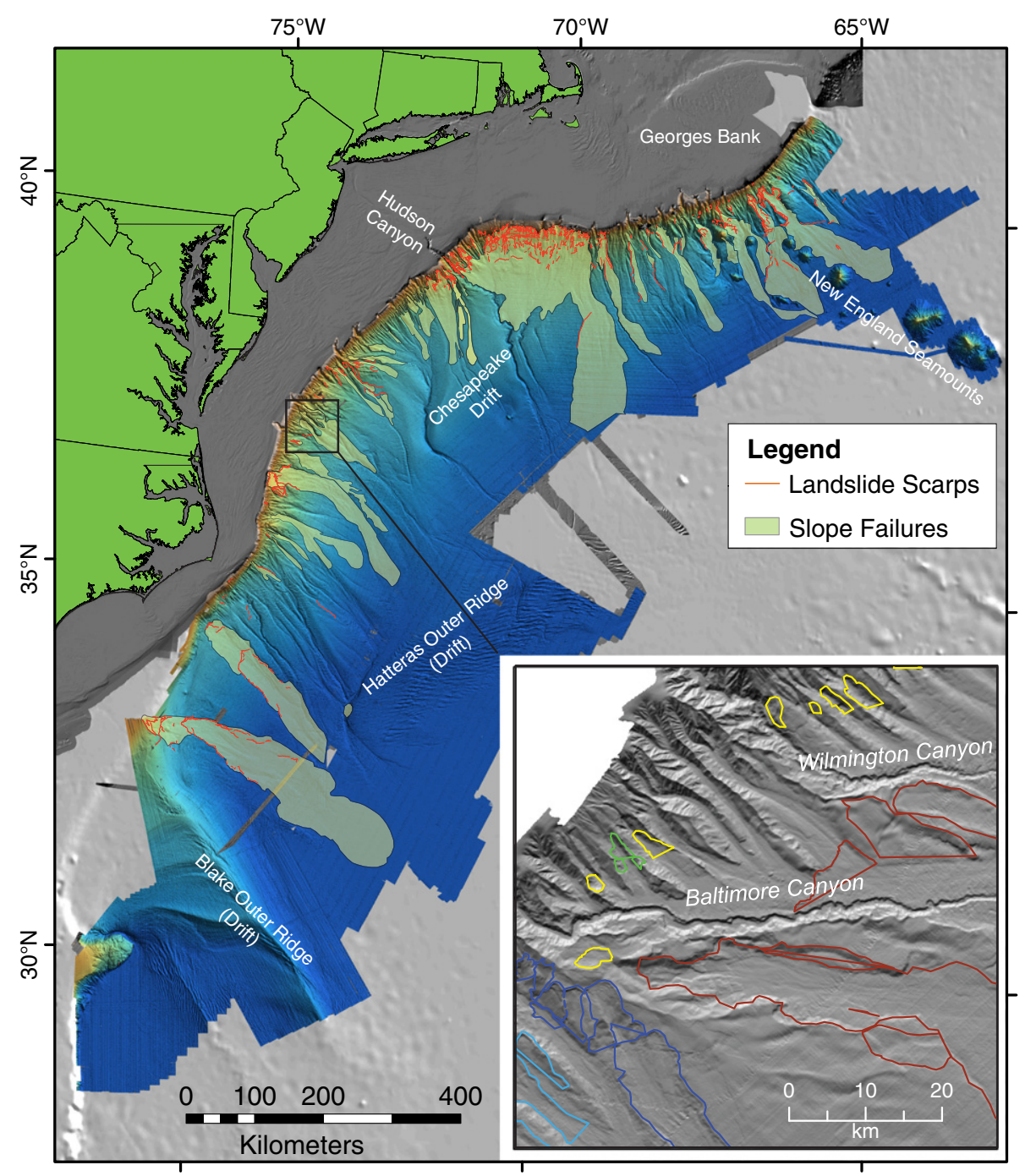

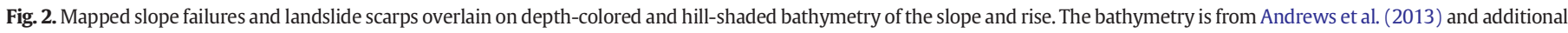

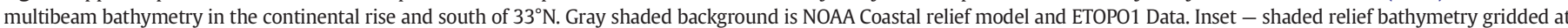

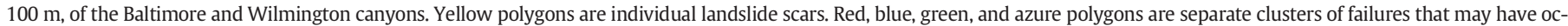
curred simultaneously (see text for discussion).

slope gradient and basic margin physiography have profound influences on depositional processes and the accumulation patterns of potentially unstable depocenters (Brothers et al., 2013a). Other factors such as weak layers, pore-fluid overpressures, and bottom stress (both transient and by salt tectonics) may also influence slope stability. We review these factors below as they apply to the U.S. Atlantic margin.

\subsubsection{Sediment supply and margin physiography}

Previous reviews of sediment supply and margin physiography (Hampton et al., 1996; Masson et al., 2006; Owen et al., 2007) have discussed the influence of sediment supply and margin physiography on the occurrence of landslides. During the Quaternary, large river systems from Virginia to Massachusetts (James, Potomac-Susquehanna, Delaware-Schuylkill, Hudson, Connecticut, and eastern Massachusetts, Fig. 1) transported fluvial and glacial sediments to the margin (Poag and Sevon, 1989). The Currituck landslide complex for example, is located seaward of buried channels in the outer shelf (Fig. 4) that were probably connected to the ancestral James and perhaps the Roanoke rivers. The primary factors that control the thickness and spatial distribution of shelf-edge depocenters are the rate of sediment supply, accommodation space (i.e., the space available for sediments to accumulate) and the gradient of the uppermost slope (compare
Fig. 5a and b). Prograding deltaic clinoforms with total thicknesses of 200-300 m underlie the shelf edge, but have been truncated by small slope failures and submarine canyon/gully incision.

Limited accommodation space during former sea level lowstands, and the proximity of the shelf edge to the steep upper continental slope (Brothers et al., 2013a) led to considerable sediment bypass to the lower slope. Poag (1992) estimated the volume of Pleistocene sediments on the shelf and upper slope to be $5 \%$ of the total sediments delivered to the margin and the volume of Pliocene sediments to be $10 \%$ of the total. A self-organized feedback loop between slope failure, pore-fluid pressures and canyon head formation (Orange et al., 1994; Pratson and Coakley, 1996) caused most sediment to bypass the slope, and thus aided the construction of rough and steep canyon-dominated slope morphology (Poag, 1992; Pratson et al, 1994; O'Grady et al., 2000; Brothers et al., 2013a).

The thickest and most extensive shelf-edge deltas occur along the Hudson Apron and Southern New England portions of the U.S. Atlantic margin (Figs. 3 and 5). Here the paleo-Hudson River and pro-glacial drainage systems supplied a mixture of fluvial and glacially derived sediment to a broad and gently inclined shelf edge/upper slope (Mountain et al., 2007). Widely spaced canyons, low mean gradients and abundant sediment supply have allowed parallel-bedded stratigraphy to prograde 

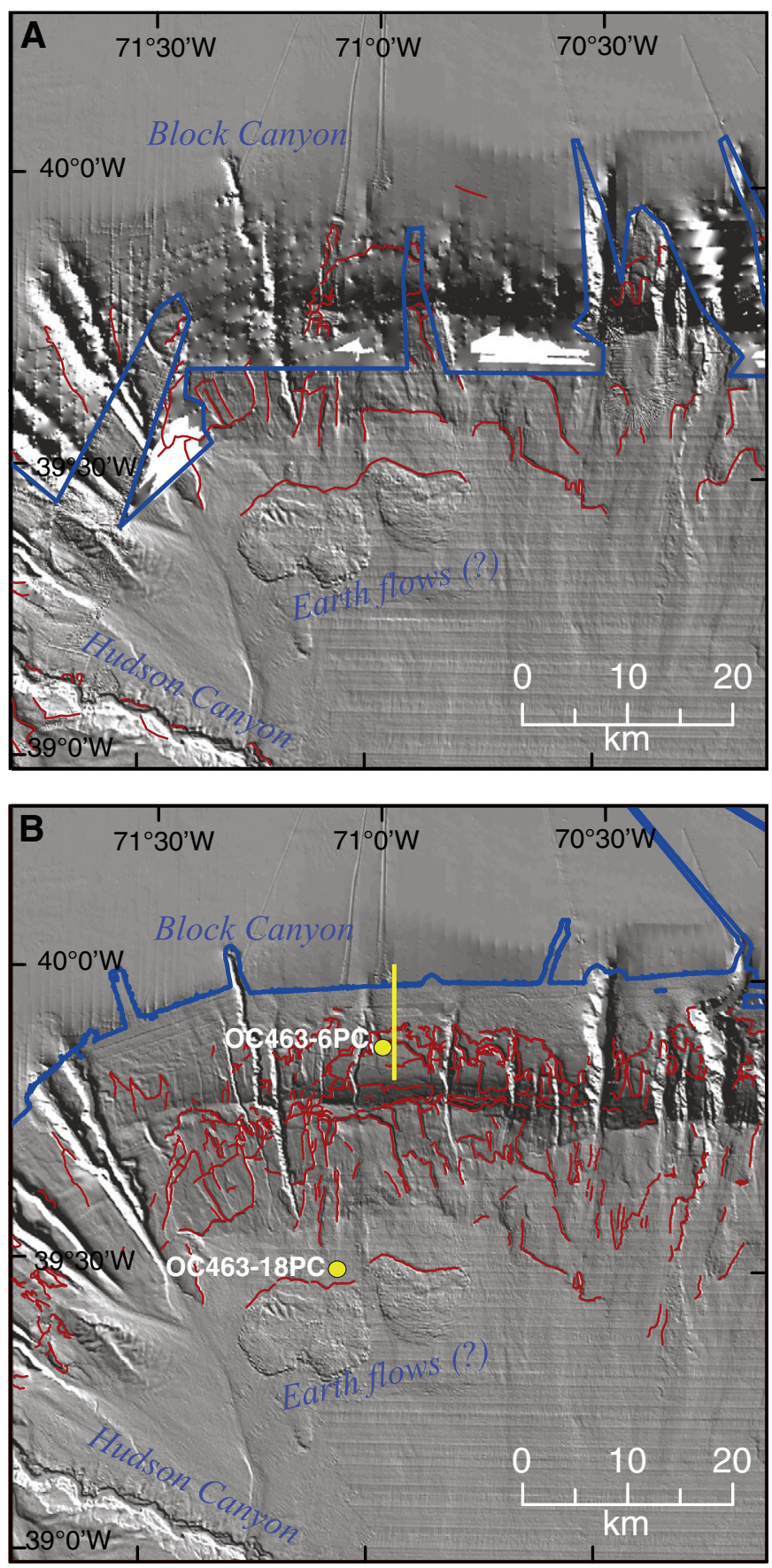

Fig. 3. Comparison of landslide scar maps of the glacial margin off Southern New England. See Fig. 1 for location. Red lines - interpretation of landslide scarps. (A) Pre-2009 data used by Twichell et al. (2009) and Chaytor et al. (2009) to map submarine landslides on the margin. (B) Latest shaded relief map from multibeam bathymetry compilation gridded at $100 \mathrm{~m}$ (from Andrews et al., 2013). Blue lines separate multibeam bathymetry data to the south from single-beam bathymetry to the north. Yellow points show locations of cores in Fig. 9. Yellow line shows location of profile in Fig. 6.

across the margin; in places Pleistocene sequences can be traced from the shelf edge to the uppermost rise (Brothers et al., 2013b, Fig. 5b). This region contains broad open-slope landslides that have failed along regionally concordant stratigraphic horizons (Figs. 3, 5, and 6). Farther northeast along the New England/Georges Bank portion of the margin, glacial outwash scoured cross-shelf troughs and delivered large volumes of glacially derived terrigenous sediments beyond the shelf-edge. The basic distribution of landslides on the slope of the New England/Georges Bank portion of the margin is similar to the Mid-Atlantic: most occur along steep, canyon-related morphology.
Again, most sediment is transported through submarine canyons and bypasses the steep upper continental slope.

\subsubsection{Weak layers}

In the Norwegian margin, predecessors of the Storegga Slide have occurred roughly every 100 ky following the glacial-interglacial cycles (Solheim et al., 2005). Solheim et al. suggested that large translational slides on that margin are controlled by the variability between glacial till and debris flows, deposited during peak glacial times and the fine-grained marine drift sediments, deposited during other times. Rapid loading by glacial sediments increases the overpressure in the underlying marine deposits. Failure, triggered by earthquakes takes place along lithological boundaries (Solheim et al., 2005). Glacialinterglacial variations in grain size and layer thickness have been documented in the New York-New Jersey shelf and shelf edge (McHugh et al., 2010) and extend to the upper slope (Brothers et al., 2014). These variations are related to the depositional environment (e.g., channels, estuaries, shelf edge) and eustatic changes (McHugh et al., 2010).

\subsubsection{Pore-fluid overpressure}

A diverse array of processes has the potential to generate pore-fluid overpressure. The most common of these processes is rapidly deposited and parallel-bedded sedimentation over an expansive area, which can generate pore-fluid overpressures (Masson et al., 2006). Where submarine canyons that truncate Pleistocene strata interrupt these areas, lateral migration pathways to open seawater conditions are created, which have the potential to lower pore-fluid overpressure (Dugan and Flemings, 2000). Along the U.S. Atlantic margin, the largest landslides occur along the gently dipping lower continental slope that contains the thickest, most widespread, and least interrupted by canyons, Quaternary strata.

Other processes that may cause pore-fluid overpressures include gas hydrate dissociation (Booth et al., 1993; Sultan et al., 2004; Phrampus and Hornbach, 2012), thermogenic and biogenic gas production from the deeper sedimentary section, subterranean groundwater flow (Person et al., 2003) and fluid expulsion due to the opal-A to opal-CT diagenesis, which occurs with progressive burial of the silica-rich chalks (McHugh et al., 1993). Diagenetic fracturing, water seepage and blocky slope failures are observed in outcropping Eocene rock of the New Jersey margin (Fig. 5; McHugh et al., 1993; Robb, 1984) and within canyons along the New England/Georges Bank margin, but their contributions to slope failures hadn't been quantified.

Dissociation of gas hydrate in the upper slope had been proposed as a major cause for slope failures (e.g., Booth and O'Leary, 1991; Paull et al., 1996; Mienert et al., 2005; Phrampus and Hornbach, 2012). The cause of the dissociation had been attributed to changing climatic or oceanographic conditions during the Holocene, or from sea level lowering during the Pleistocene. The upper stability zone of gas hydrate in most ocean margins is 300-800 m (e.g., Sultan et al., 2004; Mienert et al., 2005), and therefore, if gas hydrate disassociation is a major cause for landslides, most of the slides are expected to originate at that depth range. Older compilations (Masson et al., 2006), and new high-resolution multibeam data show that the headwalls of most landslide scarps are substantially deeper than $800 \mathrm{~m}$ (Twichell et al., 2009; Andrews et al., 2013). Of the 160 landslide scars identified in the midAtlantic slope and rise, only $9 \%$ originate shallower than $800 \mathrm{~m}$, while most of them originate at depths between 1000 and $2000 \mathrm{~m}$ (Fig. 7A).

Mean seafloor gradients in areas of landslide scars in the fluvial and glacial portions of the Atlantic margin are typically between $1^{\circ}$ and $6^{\circ}$ (Twichell et al., 2009; Fig. 7B), much less than the angle of repose for sand and silt. Although elevated pore pressure undoubtedly plays a role in facilitating failures on slopes with low gradient (Locat et al., 2009), additional horizontal acceleration, most likely by earthquake shaking is required to trigger failure (Kvalstad et al., 2005). Large slope failures on a $2^{\circ}$ slope have occurred on the NW African margin, 


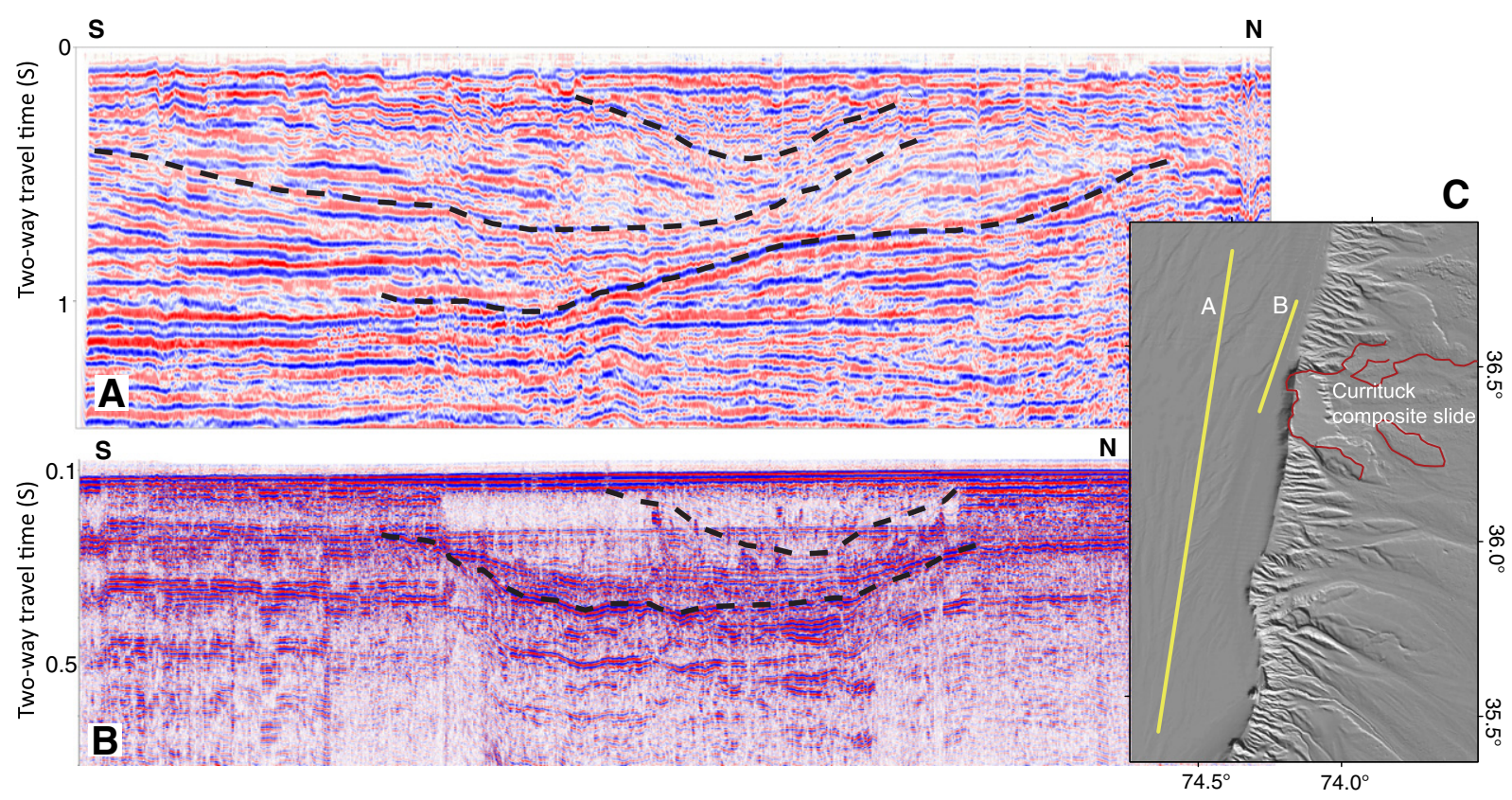

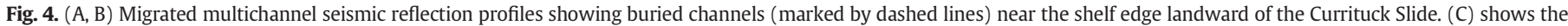
location of the seismic lines and the slide. See Fig. 1 for location.

where sediment accumulation is low and where numerical models do not predict excess pore pressure (Urlaub et al., 2012). Fluid pressures of up to $70 \%$ of the lithostatic pressure were indirectly measured on Blake Outer Ridge at 2800 m water depth (Flemings et al., 2003) but, interestingly, there are no visible slope failures on Blake Outer Ridge (Fig. 2). It is also unknown whether regions of elevated pore pressure are laterally extensive and interconnected enough to allow spontaneous failures of large seafloor areas. Elevated pore pressure within shallow sediments of the shelf and uppermost slope, vent via pockmarks, not landslides (Fader, 1991; Piper et al., 1999; Brothers et al., 2014).

\subsubsection{Transient bottom stress and salt diapirs}

Transient bottom stress produced by storm waves can be significant in shallow waters of the inner shelf, and has been documented to cause landslides (Prior et al., 1989; Hampton et al., 1996). However, these transient stresses are insignificant at slope depths $>400 \mathrm{~m}$ on the U.S. Atlantic margin (Dalyander et al., 2013; Soupy Dalyander, pers. Comm., 2013) because the depth of effective bottom stresses is a function of the wavelength of ocean swells, and the largest swells are shorter than several hundred meters. The Western Boundary Undercurrent (WBU) has facilitated erosion, transport and deposition on the lower slope since the Oligocene (Mountain and Tucholke, 1985). The WBU did not generate landslides in recent times, as evident by the lack of landslide scars on the drift-formed Blake Ridge (Fig. 2). In addition, the WBU presently runs over the Hatteras Drift and thus has minimal effect on the continental slope (Figs. 1 and 2).

Landslide excavation and canyon erosion can locally result in over-steepening of unstable deposits, leading to additional failure (e.g., retrogressive failures of the open slope). Other possible sources of over-steepening are rising and/or horizontally migrating salt diapirs off North Carolina (Dillon et al., 1982; Fig. 1). Salt diapirs are typically mobilized by extension or partial unroofing of the brittle overburden (e.g., Vendeville and Jackson, 1992). Along passive margins, such as the Atlantic margin, mobilization of the salt diapirs may be the result of erosion by bottom currents. The migration rate of the salt diapirs in the vicinity of Cape Hatteras is presently unknown, hence the probability for slope instability caused by their ascent, cannot be determined. Two of the largest slides on the Atlantic margin, the Cape Fear and Cape
Lookout slides ( 4 and 5 in Fig. 1) are sourced in this area of salt diapirs (Dillon et al., 1982; Hornbach et al., 2007).

\subsection{Landslide ages}

\subsubsection{Empirical arguments}

Estimating submarine landslide recurrence is a pre-requisite for probabilistic hazard assessment of landslide tsunamis. Estimating submarine landslide recurrence is, however, challenging because of several reasons: it is difficult to detect submarine slope failures in real time, robust dating of old slides is time consuming (e.g., Haflidason et al., 2005; Urlaub et al., 2013), and the geologic record of older landslides is often erased by the latest landslides or covered by sediment. Indirect arguments can help constrain the temporal distribution of landslides, provided they can be justified. One such argument is the ergodic assumption in which the temporal distribution of landslides around the globe can yield the rate of landslide occurrence at a particular location. However, this argument assumes a landslide distribution independent of the specific environment, such as the level of seismicity, the rate of sediment supply, and the pre-Pleistocene morphology of the margin, assumptions which are probably not justified.

Empirical arguments have been made to explain the apparent higher rate of submarine landslides around the world between $\sim 25,000$ and 7000 yr BP (Masson et al., 2006; Owen et al., 2007; Lee, 2009). These arguments include 1) the higher amount of sediment delivered to the margins by glaciers, by catastrophic draining of glacial lakes, and by increased erosion due to past wetter conditions, 2) the higher amount of sediment, expected to reach the slope during low sea level, 3) the expected increase in pore pressure of slope sediments because of the rapid accumulation of sediments (Dugan and Flemings, 2000; Kvalstad et al., 2005; Flemings et al., 2008), and 4) the possible increase in the rate of seismicity due to unloading of the lithosphere by the melting ice sheets (Lee, 2009) and/or rapid sea level rise (Brothers et al., 2013c).

A recent global compilation of landslide ages (Urlaub et al., 2013) shows, however, a random distribution of landslide ages throughout both the glacial and interglacial periods (Fig. 8), with perhaps only landslides occurring in river fan systems being more frequent since the LGM (Urlaub et al., 2013). In addition, this distribution may be unintentionally 

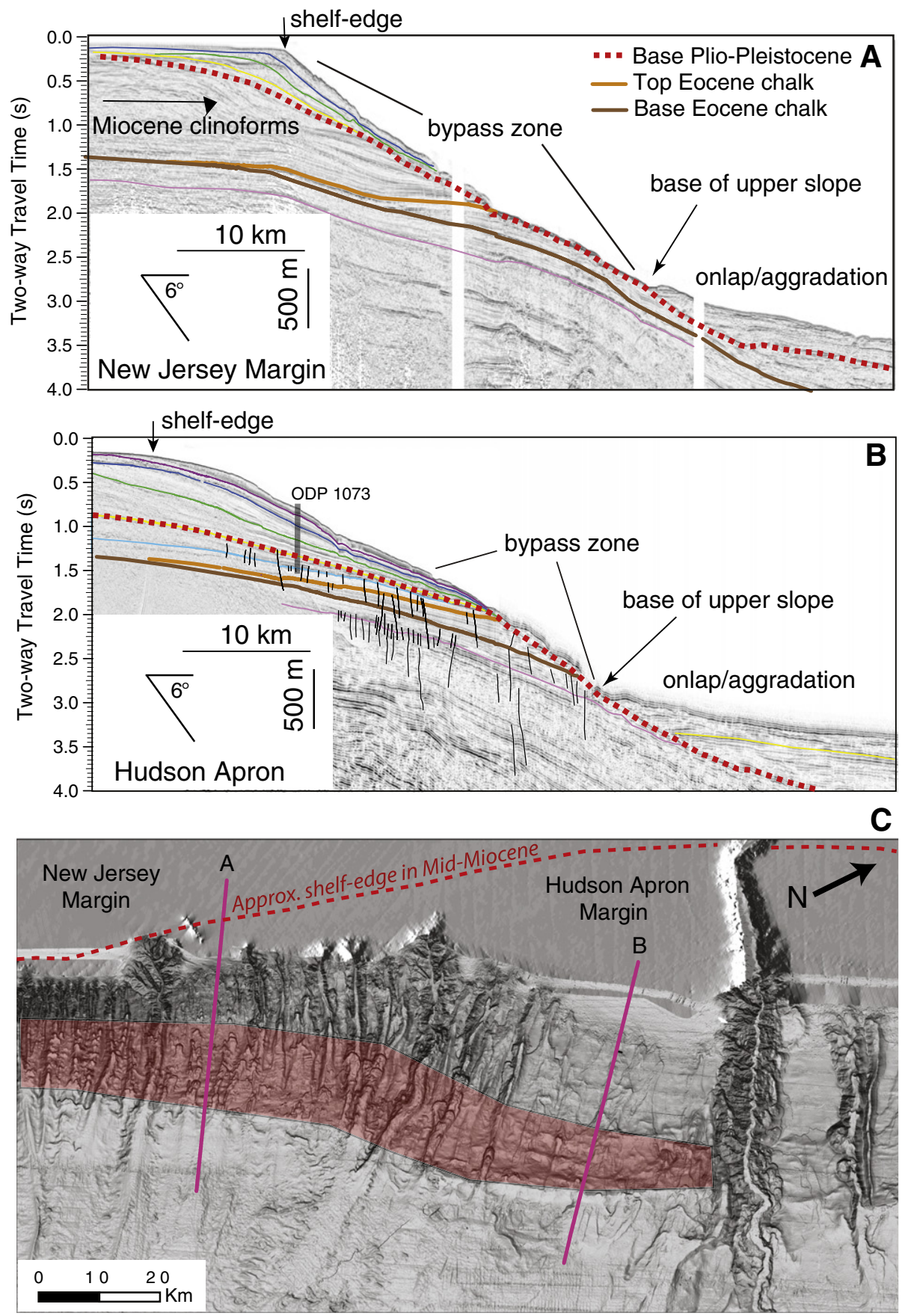

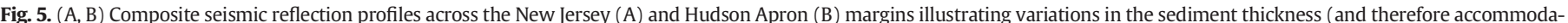

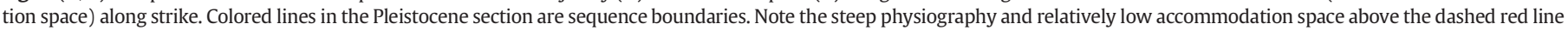

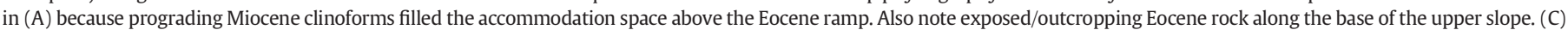

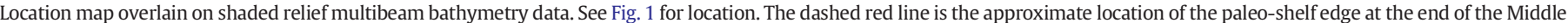
Miocene (e.g., the clinoform rollover). Shaded brown region is the approximate extent of exposed Eocene chalk.

skewed toward younger ages because newer landslides and sedimentation may erase evidence for older landslides. Urlaub et al., (2013) noted however an unexplained decrease in the rate of slope failures during the past $6000 \mathrm{yr}$, which coincides with the end of the bulk of sea level rise since the LGM.

\subsubsection{Absolute dating}

Embley (1980) provided the most extensive record of radiocarbon ages for landslides along the U.S. Atlantic margin compiled to date. These ages are limited to just two areas, the Cape Fear slide (marked 5 in Fig. 1) and a section of the slope immediately south of Baltimore
Canyon (Fig. 2-inset). Ages at the base of hemipelagic sediment overlying the youngest MTDs in the Baltimore Canyon slide zone range between $5200 \pm 150$ and 10,080 yr BP (radiocarbon years) while ages of sediment overlying MTDs of the Cape Fear landslide vary between 12,125 and 20,830 yr BP (radiocarbon years). The age of a marked strength boundary at the top of ODP core Site 991A, interpreted to be a slide plane of the youngest failure phase of the Cape Fear landslide, is between 10,000 and 27,000 yr BP (Rodriguez and Paull, 2000). Additional dating of sediments collected by piston coring above and below slide planes of the Upper Cape Fear landslide place the age of failure between 9000 and 29,000 yr BP (Paull et al., 1996). The different 


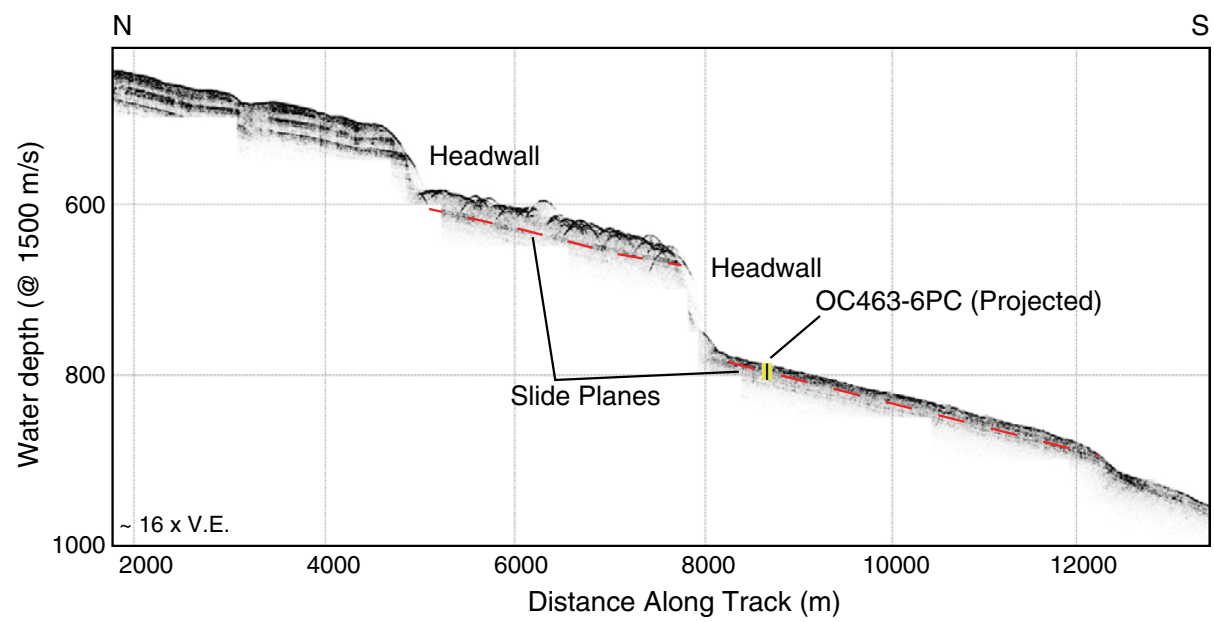

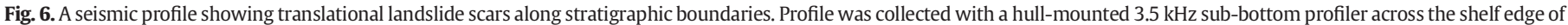
southern New England (in the glaciated region of the margin). See Fig. 3B for location.
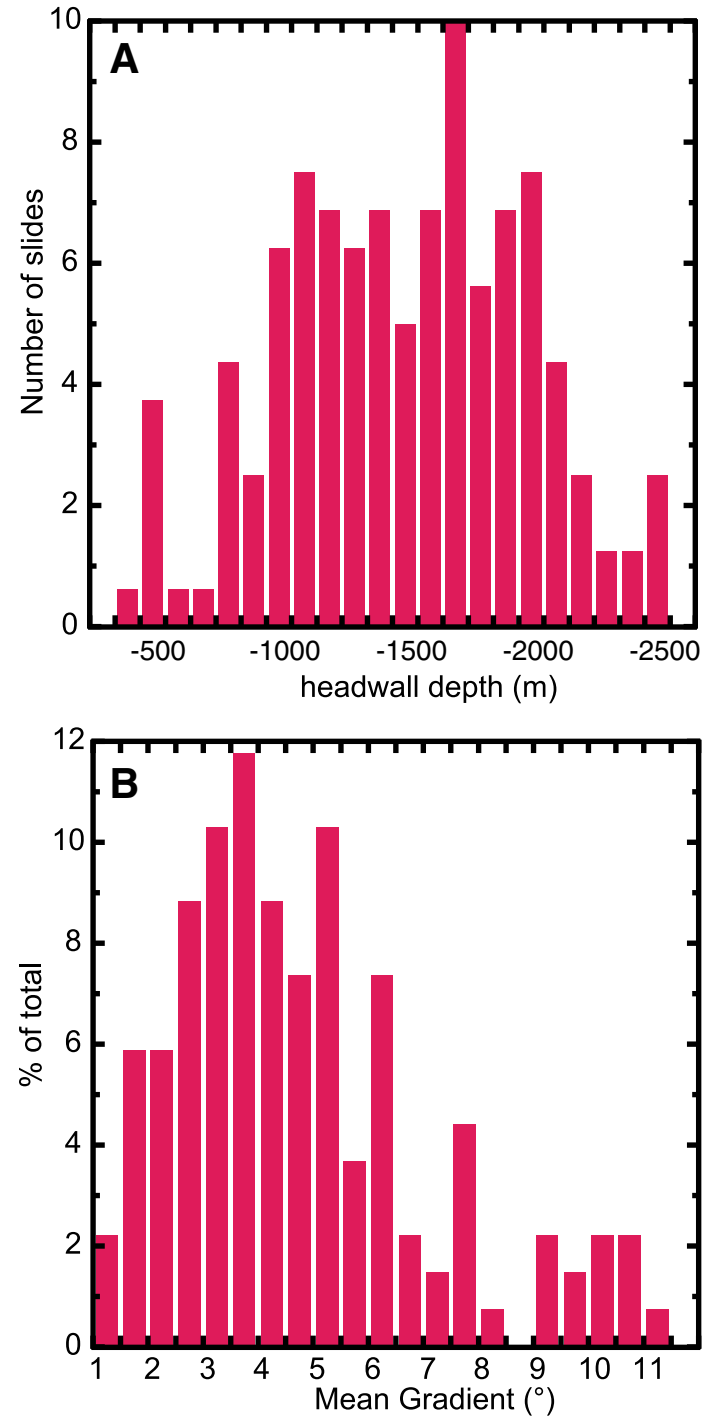

Fig. 7. (A) Histogram of depths of headwalls from 160 landslide scars in the mid-Atlantic region (ten Brink et al., 2012). Note that the most frequent headwalls occur in depth ranges from 1000 to $2000 \mathrm{~m}$, much deeper than the 300-800 m depth range of the upper stability zone of gas hydrate. (B) Histogram of the mean gradients of 160 landslides in the mid-Atlantic region (ten Brink et al., 2012). The gradient is the mean gradient of a smooth surface that stretches between the points defining of the tops of the landslide scarp, which to a first approximation represents the pre-failure surface. age ranges for the Cape Fear landslide may represent the occurrence of multiple failures (including retrogressive processes) during the late Pleistocene-Holocene period.

We have collected 40 piston cores along the southern New England portion of the margin (Fig. 3b) and within the Currituck landslide evacuation zone and MTD (Fig. 4) to constrain the ages of failures in these areas (Chaytor et al., 2011, 2012b). Coring of the Type 2 landslides in southern New England has focused on dating sediments above the slide planes at shallow (500-900 m) and intermediate (1500$2000 \mathrm{~m}$ ) slope depths, and above MTDs on the lower slope at depths of 2400-2600 m. Slide planes were intersected in several cores and preliminary ages based on AMS ${ }^{14} \mathrm{C}$ dating of planktonic foraminifera indicate that these failures occurred prior to the Holocene (Chaytor et al., 2012b) (Fig. 9a). Hemipelagic and pelagic sediments above MTDs on the lower slope, including MTDs that incorporate earlier deposits into an earthflow-type landslide on the lower slope (Locat et al., 2010; Fig. 3), were dated using biostratigraphic indicators (G. menardii) and preliminary ${ }^{14} \mathrm{C}$. The dates indicate that the last recorded failure events occurred between 10,000 and 20,000 yr BP (Fig. 9b). Additional dating and sedimentological analysis are being performed to refine these ages.

The age of the Type 1 Currituck landslide (see Fig. 1 slide \#3 for location), which could have generated a significant tsunami (Geist et al., 2009a, 2009b), has previously been assigned post-Early Pleistocene age (Bunn and McGregor, 1980) to between 17,000 and 50,000 yr (Prior et al., 1986). These age estimates were based primarily on sediment accumulation rates, not from absolute ages. The sedimentation rates were derived from cores collected offshore of New Jersey and Delaware. These cores do not capture the variable sediment accumulation rates in the Currituck area, which can range from 10 to more than $100 \mathrm{~cm} / 1000 \mathrm{yr}$ (Alperin et al., 2002; Thomas et al., 2002). Initial analysis of cores we collected in 2012 from the Currituck landslide suggests that part or the entire landslide may be late Pleistocene post LGM in age, but detailed work to establish timing of the landslide has only just begun.

\subsubsection{Cable breaks along the margin}

Submarine telecommunication cable breaks are an important clue to the occurrence of submarine landslides (Fine et al., 2005; LópezVenegas et al., 2008). Lockridge et al. (2002) published a summary compiled by de Smitt in 1932 of telegraph cable breaks along the U.S. Atlantic coast. The summary lists 12 cable breaks during the period between 1899 and 1925, with all but one of them located offshore Long Island and New England between Lat. $39.8^{\circ} \mathrm{N}$ and $41.0^{\circ} \mathrm{N}$. One other break was located at the boundary between the shelf and Blake 


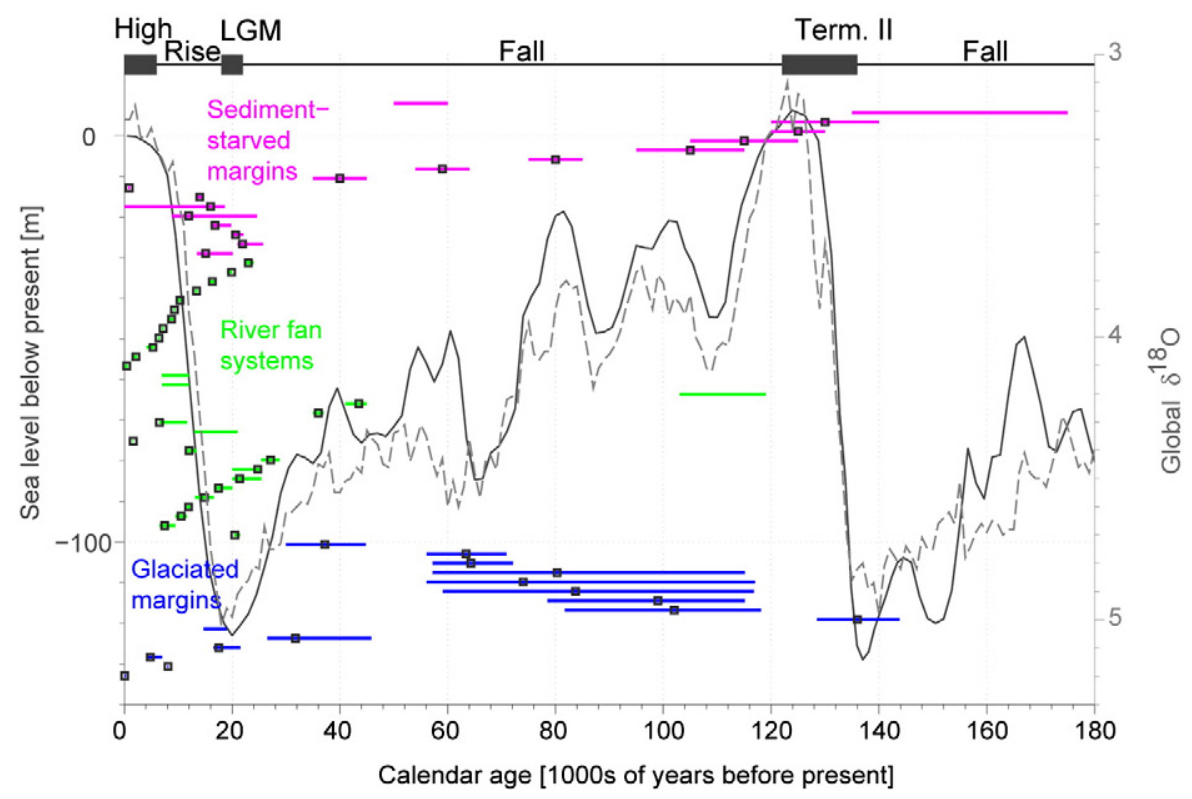

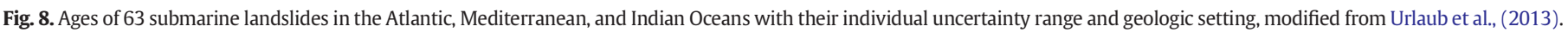

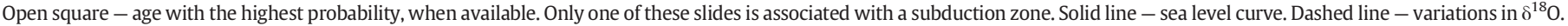

Plateau offshore Brunswick, GA. If cable breaks are indicative of submarine landslides, then slope failures have happened at the turn of the 20th century. The spatial distribution of these possible landslides reflects however, the distribution of underwater cables, and is not necessarily representative of landslide distribution along the margin. A database of more recent cable breaks is unfortunately no longer available publicly.

\subsection{Statistics of landslide distributions}

Submarine landslide studies often try to derive failure and transport processes by observing and sampling in detail a specific landslide (e.g., Bondevik et al., 2005; Locat et al., 2009). A different approach to understanding submarine landslide mechanics is to extract their characteristics from statistics performed on numerous landslides within a geographical region. Such an approach has been implemented for more than a decade in subaerial landslide studies, where detailed digital terrain models (DTM) are available (e.g., Stark and Hovius, 2001; Guzzetti et al., 2002). This approach has been slow to develop in the submarine environment, where a bathymetric terrain model (BTM) depends on the availability of regional high-resolution bathymetric datasets (ten Brink et al., 2006a; Micallef et al., 2008; Chaytor et al., 2009).

The compilation of bathymetric data along the U.S. Atlantic margin at a grid interval of $100 \mathrm{~m}$ (Fig. 1; Andrews et al., 2013) allowed us to identify all but the very small $\left(<1 \mathrm{~km}^{2}\right)$ landslide scars and calculate
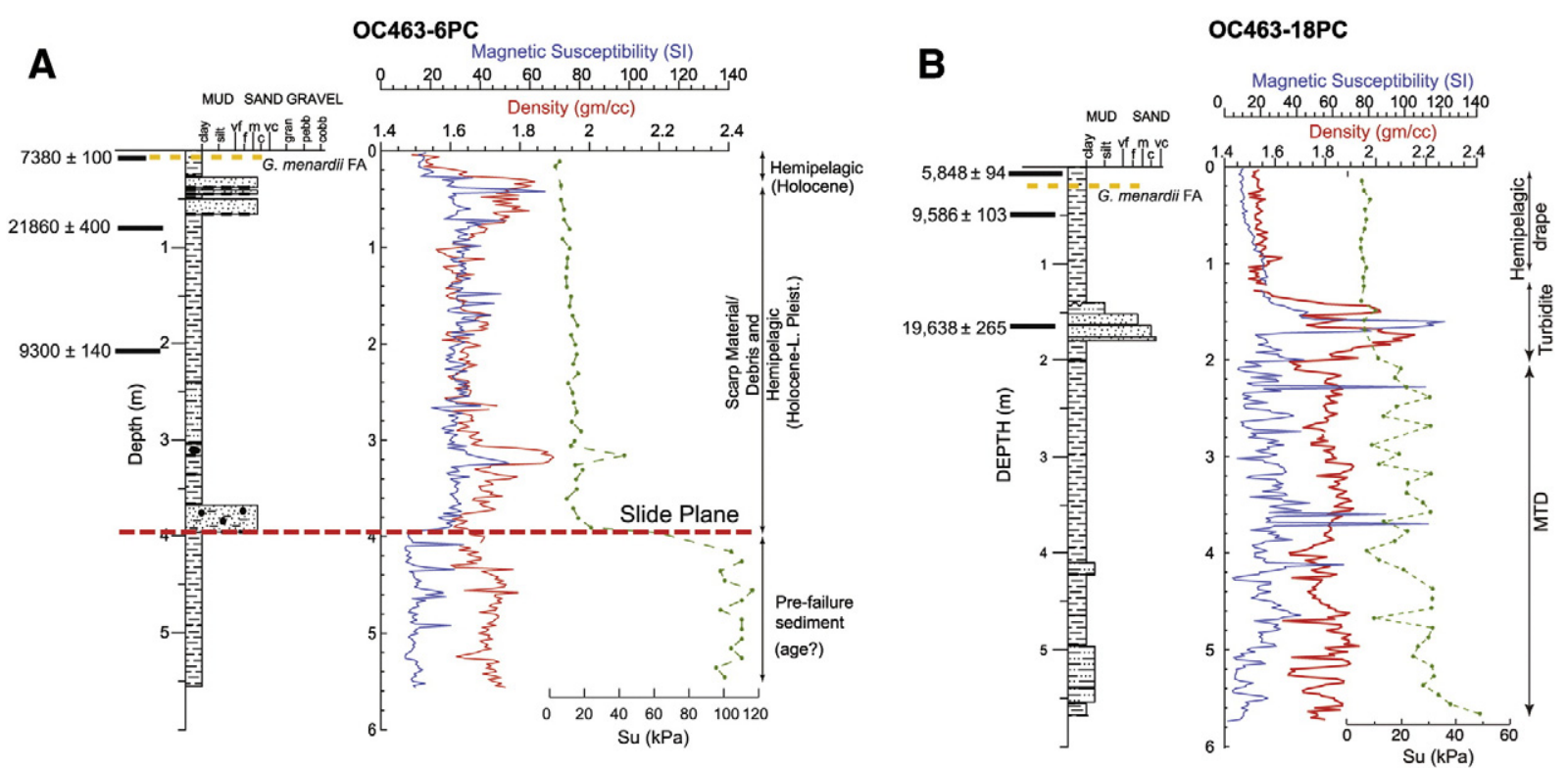

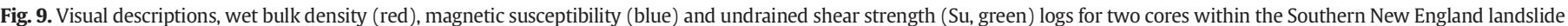

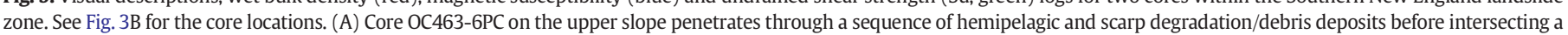

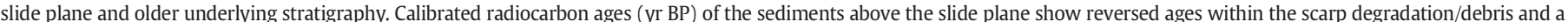

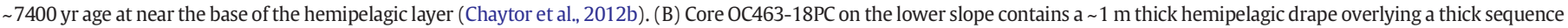

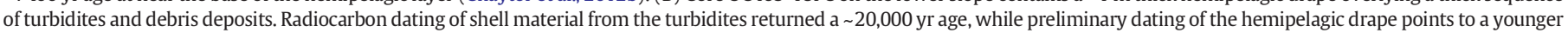
Holocene-Latest Pleistocene age. G. menardii FA - first abundant appearance of Globorotalia menardii. 
their areas and volumes. Landslide volumes were calculated by interpolating smooth surfaces through polygons that define the scarps of each slide, then gridding these smooth surfaces, and finally, subtracting these grids from the gridded topography of each scar (ten Brink et al., 2006a; Chaytor et al., 2009). These compilations show several interesting relationships. Landslide volume increases almost linearly with area ( $\mathrm{V}=\mathrm{kA}^{\mathrm{d}}$, where $\mathrm{d} \sim 1.1$ ) (Fig. 10a), implying that the thickness of most slides is independent of the landslide area. This leads to the inference that most landslides on the margin must be translational, failing along depositional layer boundaries separating units of similar thickness, and having low shear strength (Fig. 11). Bathymetry and
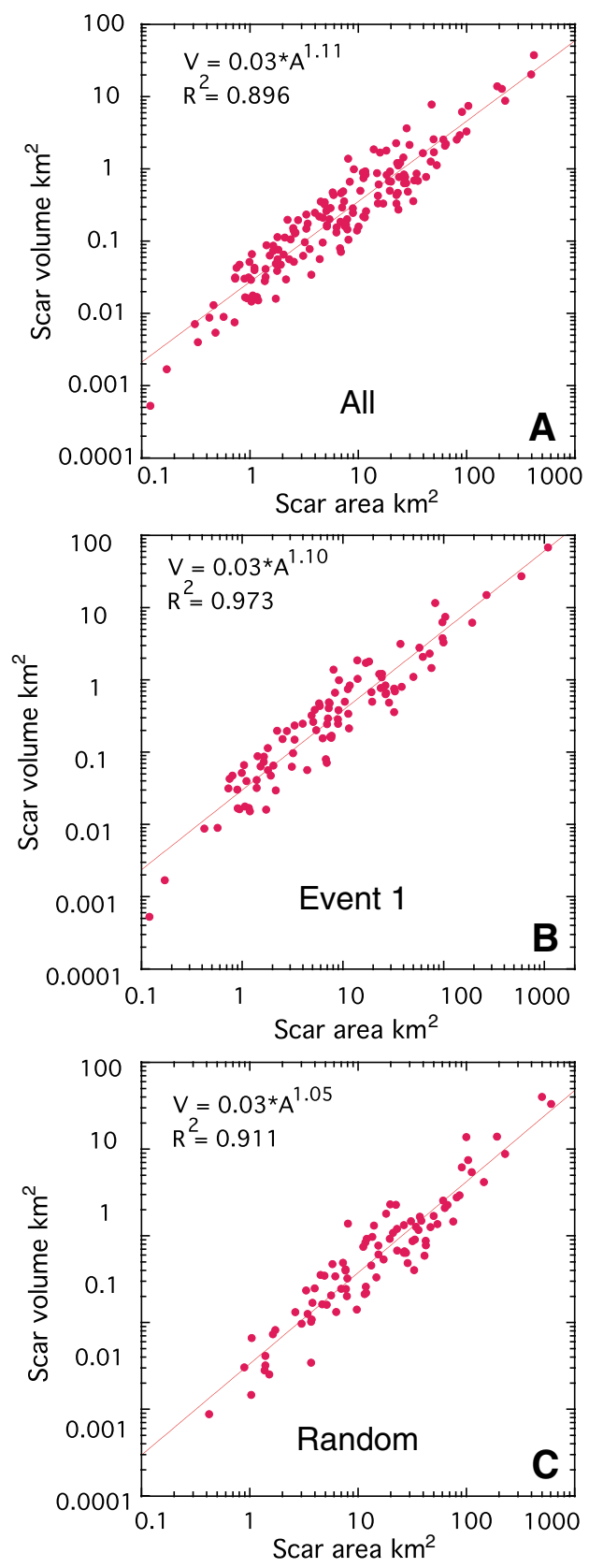

Fig. 10. (A) Area-volume relationship for 160 landslide scars in the mid-Atlantic margin. See text for the procedure to calculate the volumes. (B) Same plot after subjectively clustering nearby landslide scars that may represent simultaneous failures during the same earthquake event. See Fig. 2-inset for examples of clusters. The total number of independent landslide scars is 98 . Note that clustering improves the area-volume fit significantly. (C) Same plot using random clustering of the 160 landslides into 90 landslides. Random clustering of the 160 landslides does not result in a significant improvement of fit and demonstrates that the improved fit is not the result of a smaller sampling group.

\section{Translational slide}

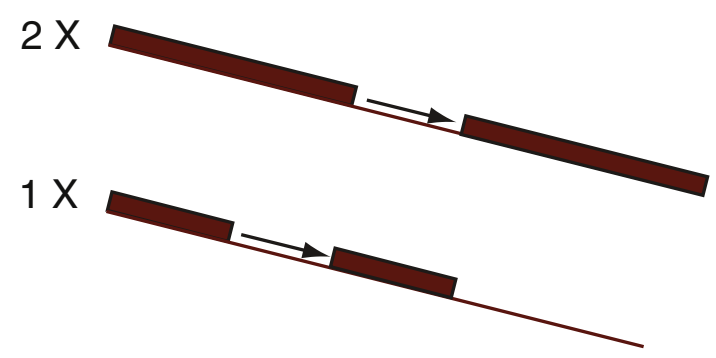

Rotational slide

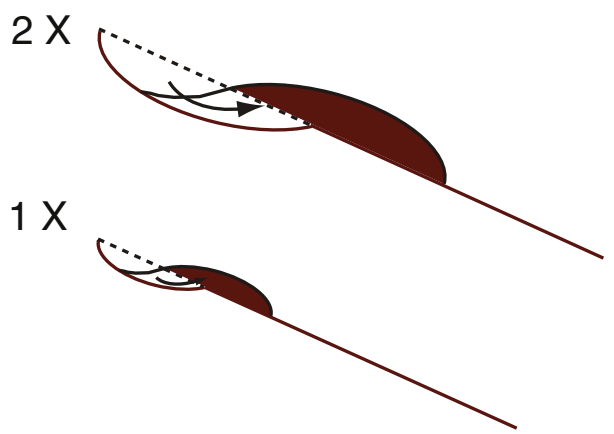

Fig. 11. Schematic drawings of translational and rotational slides each with one and two times scar length. Note that for rotational slides, doubling the scar length increases the slide thickness, but for translational slides, the thickness remains unchanged. The change in slide thickness with slide area is expressed by the value of the exponent in landslide volume to area relationships: an exponent of 1 represents translational slides and $\leq 1.5$ represents rotational slides.

high-resolution seismic reflection data along the margin indeed indicate failure of thin (20-200 m thick) broad layers (Twichell et al., 2009; ten Brink et al., 2012; Fig. 6). This is in contrast to volume-area relationships of subaerial ( $\mathrm{d}=1.5$, Hovius et al., 1997$)$ and submarine $(\mathrm{d}=1.3$, ten Brink et al., 2006a) landslides in lithified rocks. In these environments, slide depth increases as the square $(d=1.5)$ or cube $(d=1.25)$ root of the area, indicating that they are mostly rotational or rock falls (Fig. 11).

Without dating landslides, it is difficult to know whether shaking of a large area by a single earthquake generated several adjacent scars, or if the scars formed separately during a longer time period. Using new interpretations of the bathymetry data (ten Brink et al., 2012), we subjectively clustered nearby landslide scars (e.g., Fig. 2-inset), assuming that they represent a single failure event, reducing the number of independent landslide scars in the mid-Atlantic region from 160 to 98. The volume-area relationship of these 98 "independent" scars shows a much better fit $\left(R^{2}=0.97\right)$ than a similar fit to all 160 scars (Fig. 10b). The improvement is not simply a function of the reduction in the number of landslides, because random clustering of the landslides does not improve the fit (Fig. 10c). We thus propose that landslides that fail together have much tighter volume-area relationships.

An analysis similar to that described above has not been performed on landslides located on the carbonate margin of the southern U.S.; however, an analog to this margin is provided by failures along the edge of the carbonate margin north of Puerto Rico (ten Brink et al., 2006a). The volume-area relationship of 160 landslide scars there is $\mathrm{V}=\mathrm{k} \mathrm{A}$, where $\mathrm{d} \sim 1.3$ (Fig. 14b), suggesting that landslide volume increases more rapidly with increasing area than in the salt, fluvial, and glacial portions of the Atlantic margin, indicating that failure occurs either by rotational slides, or by large rock falls. Seafloor gradients in which these landslides occur often exceed $20^{\circ}$ and may reach $45^{\circ}$ (ten 
Brink et al., 2006a). The carbonate margin surrounding Florida is likewise steep, reaching near-vertical angles in the Blake Escarpment (Dillon et al., 1985). The statistics and distribution of slope failures in lithified carbonate rocks are therefore very different than in the unlithified siliciclastic sediment of the Atlantic margin, as will be further discussed below.

\subsection{Using landslide statistics to infer relationships between earthquakes and landslides}

Earthquake probability is used to estimate maximum landslide tsunami probability, by relating landslide area and volume to earthquake magnitude. This approach is used because the vast majority of landslides tsunamis are associated with earthquakes, and because tsunami height scales with landslide volume (ten Brink et al., 2009a).

The cumulative distribution of both volume and area of submarine landslide scars along the U.S. Atlantic margin follow a lognormal shape (Chaytor et al., 2009). In other words, there are finite numbers of small landslides, very few large landslides, and most landslide scar areas fall between $3 \mathrm{~km}^{2}$ and $500 \mathrm{~km}^{2}$. A similar distribution is derived from analysis of new high-resolution bathymetry data from the midAtlantic region (ten Brink et al., 2012; Fig. 12A). Similar area and volume distributions were also obtained by considering subsets of the data that exclude poorly defined scars and by grouping scars that might have failed together, indicating that these distributions are statistically robust (ten Brink et al., 2012; Fig. 12A).

Using Monte Carlo simulations, ten Brink et al. (2009a) reproduced the observed lognormal cumulative distribution of landslides (Fig. 12B) with two simple assumptions: 1) infinite slope stability analysis is used to calculate the acceleration needed to displace seafloor sediments, and 2) horizontal acceleration is provided by earthquake shaking whose amplitude and attenuation with distance from the fault depend on earthquake magnitude. To calculate the maximum landslide area as a function of the magnitude of the triggering earthquake, ten Brink et al. (2009b) used published peak spectral acceleration curves for the eastern U.S., sediment shear strength, and empirical observations that indicate that horizontal acceleration should exceed the factor of safety significantly to cause catastrophic displacements. The good fit between the cumulative distributions of observed landslides in the Atlantic margin and that calculated from slope stability analysis and horizontal acceleration of earthquakes (Fig. 12B), suggests that landslide area and volume can be related to earthquake magnitude (ten Brink et al., 2009a). Earthquake probability could be used to predict submarine landslide probability, because earthquake rates are better defined from instrumental monitoring than rates of submarine landslides that largely go unmonitored. Note however, that this method only predicts the maximum landslide size, whereas in reality, local rheological and geotechnical (e.g., pore pressure) variations may prevent or facilitate failure in parts of a region. Simulations described in ten Brink et al. (2009a) in fact, fit the observed landslide distribution better if the actual failure area falls between 0.3 and 1 of the maximum predicted failure area.

Although seismic activity has been detected along the mid-Atlantic and New England portions of the margin (http://www.bc.edu/content/ bc/research/westonobservatory/jpg/NEUS_1975_Oct2013_web.jpg, accessed 02.01.2014), there is currently no reliable probabilistic estimate for earthquake activity along the offshore margin. The continental slope off eastern Canada from the Arctic to the Scotian margin experiences a relatively high rate (for intra-plate regions) of seismic moment release, which is equivalent to an M7 earthquake occurring somewhere along that 6000-km-long margin every 40-200 yr (Mazzotti and Adams, 2005). If the seismicity along the Scotian margin is caused by stress changes from glacial rebound, then estimates of the rate of seismic moment release from this region can perhaps be extended south to the 400-km-long New England/Georges Bank portion of the margin, which has also experienced glacial rebound. Assuming homogeneity in the spatial distribution of intra-plate earthquakes (Swafford and Stein, 2007), the expected rate of seismic moment release along the New England margin is $400 / 6000 \mathrm{~km}$, or $1 / 15$ that of the estimated seismic moment release for the Canadian margin; which equals an M7 occurring every 600-3000 yr. Ocean bottom seismometers just recovered from the southern New England slope will hopefully illuminate the occurrence of microseismicity and help to improve the estimate of earthquake probability along the continental slope and rise.

We can use the relationship between earthquake magnitude and landslide distribution to make other predictions about landslide occurrence. First, even the largest expected earthquakes along the U.S. Atlantic margin (M7.5, Frankel et al., 1996) must be located within $100-150 \mathrm{~km}$ of the continental slope and outer rise to generate landslides
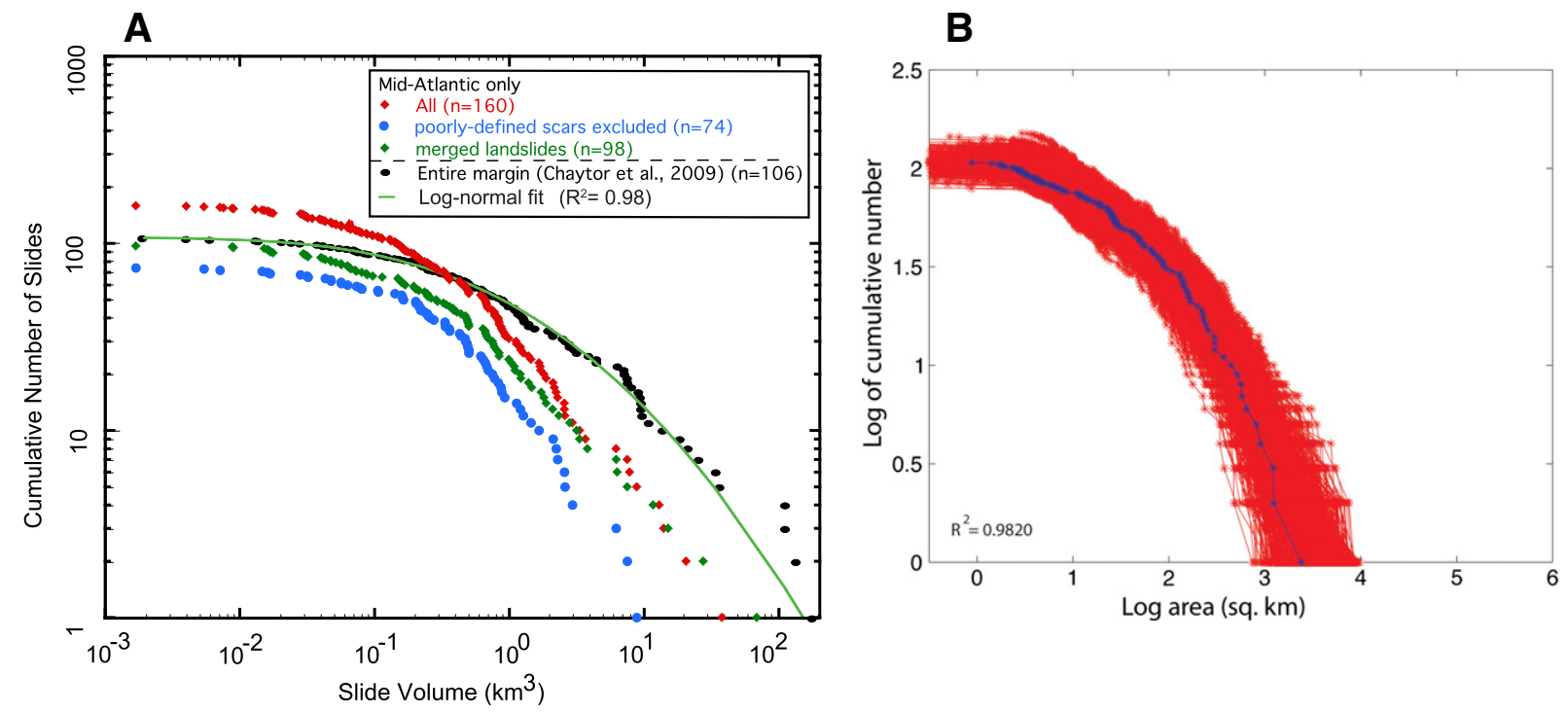

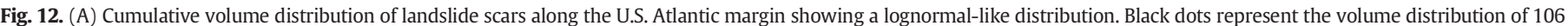

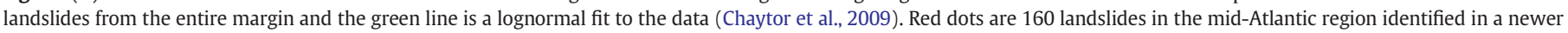

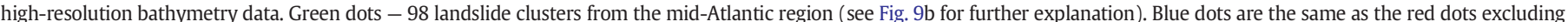

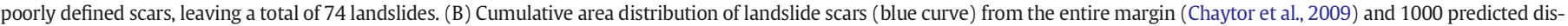

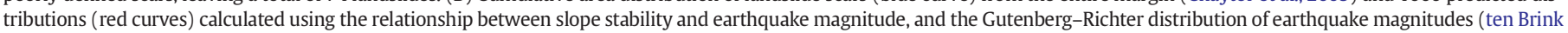
et al., 2009a). 
(ten Brink et al., 2009b). This provides a conservative guideline for issuing tsunami warnings following an earthquake offshore the eastern U.S. Second, the acceleration from very small earthquakes $(<\mathrm{M} 4.5)$ is too small to cause significant landslides even if the earthquakes are located under the continental slope. Keefer (1984) made similar empirical observations for the continental U.S. (Fig. 13), namely, earthquakes with local magnitude $\mathrm{M}_{\mathrm{L}}<4$ do not generate landslides, and $\mathrm{M}_{\mathrm{L}}<5$ earthquakes may not generate rock slumps, block slides, rapid soil flows, and subaqueous landslides.

\subsubsection{Landslide distribution in carbonate margins}

The southern portion of the margin is composed predominantly of carbonate material. Carbonate margins are characterized by steep slopes $\left(\geq 45^{\circ}\right)$, reflecting the strong cohesion of carbonate rocks. Landslide sizes along the carbonate rock margin of Puerto Rico follows an inverse power law distribution, not lognormal-like (ten Brink et al., 2006a; Fig. 14). This distribution can be explained if slope failures during earthquakes follow pre-existing fissures and fractures in the carbonate platform. Fissures and fractures were observed in multibeam bathymetry data collected at the edge of the Puerto Rico platform (ten Brink et al., 2006b). They probably develop by tensile stresses and grow by carbonate dissolution in a system of seawater circulation. Tensile fracture systems (Katz and Aharonov, 2006) and faults (Scholz and Cowie, 1990) have been shown to obey an inverse power law distribution in the lab and in the field, attesting to their progressive development with time.

\subsection{Landslide initiation: landslides as aggregate failures}

The relationship between landslide area or volume and earthquake magnitude, has an important implication to the initiation mechanism of translational landslides. Slope destabilization can occur simultaneously within the area affected by horizontal ground shaking, and not propagate from one or a few nucleating points (Fig. 15). Propagation may be generally limited to several hundreds of meters (e.g., Laberg and

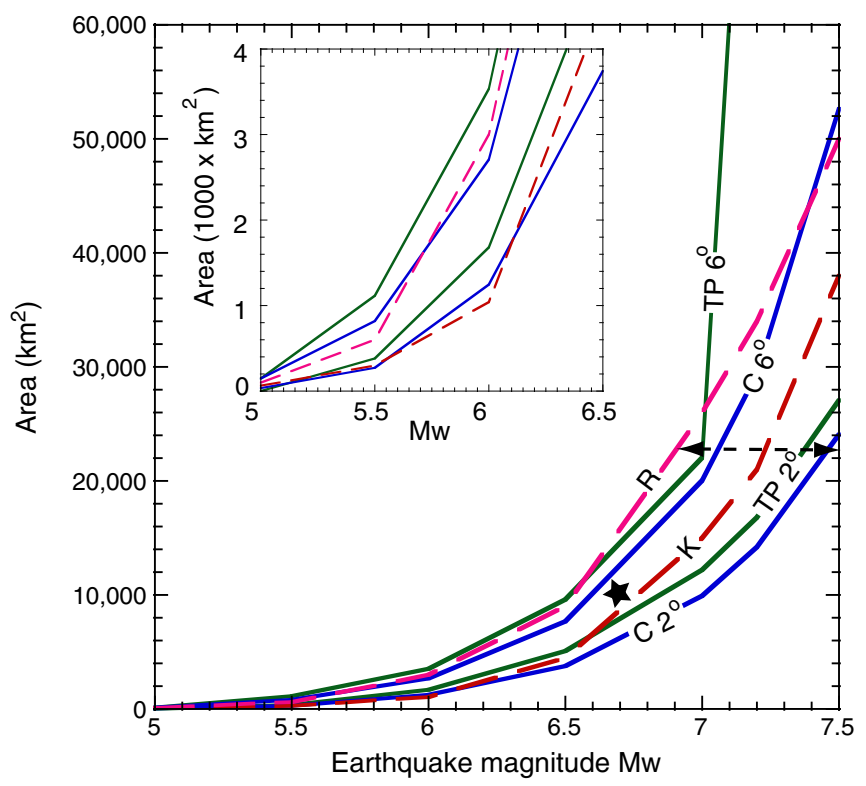

Fig. 13. Comparison between two methods used to derive the relationship between earthquakes and landslide areas. Solid curves were calculated by the slope stability analysis method for seabed gradients of $2^{\circ}$ and $6^{\circ}$ using two published peak spectral acceleration relationships for the eastern U.S, (marked C and TP). Long, red dashed curves are empirical relationships of maximum failure area on land, K (Keefer, 1984) and R (Rodriguez et al., 1999). Inset is an enlargement of low earthquake magnitudes. The star represents the total area affected by landslides due to the M6.7 Northridge earthquake. The doublearrowed dashed line is the 1929 Grand Banks earthquake magnitude range and the maximum estimated failure area (Mosher and Piper, 2007).
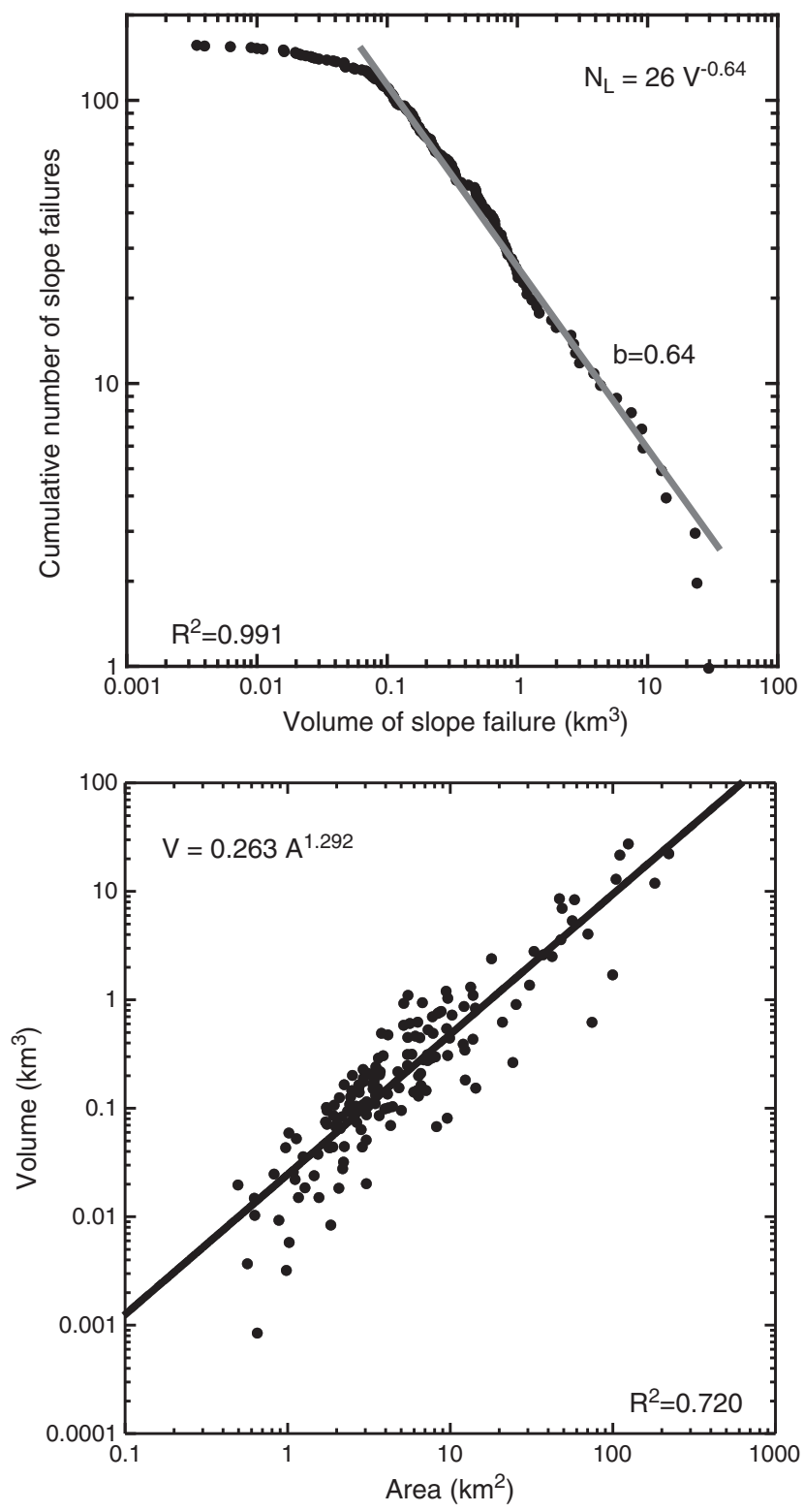

Fig. 14. (a) Cumulative volume distribution of submarine slope failures north of Puerto Rico. Dots - observations. Line - best fit regression line on a log-log plot. (b) area-volume distribution for 160 landslide scars in the carbonate margin north of Puerto Rico.

Vorren, 2000). The many separate terrestrial landslides that are generated by a single earthquake represent many independent nucleating points within the affected area, which fail almost simultaneously (Fig. 15). How much of that area will actually fail depends on local variations in gradient, material strength, pore pressure, and the presence of pre-existing fractures.

Several observations support our hypothesis of many nucleating points. First, the total seafloor area affected by the 1929 Grand Banks landslide is estimated at $22,700 \mathrm{~km}^{2}$ yet detailed seafloor maps show complete failure in only $1 / 3$ of that area, whereas in the remaining $2 / 3$ of the area patches of failures are interspersed with seafloor patches where failure was not detected (Mosher and Piper, 2007). Second, the total area encompassing all the terrestrial landslides from a particular earthquake is a function of that earthquake magnitude (Keefer, 1984; Rodriguez et al., 1999) and is comparable to the area calculated for the Atlantic margin from slope stability analysis, (Fig. 13; ten Brink et al., 2009a).

Subaerial landslides have previously been viewed together with other natural hazards, such as earthquakes and fires, as phenomena 

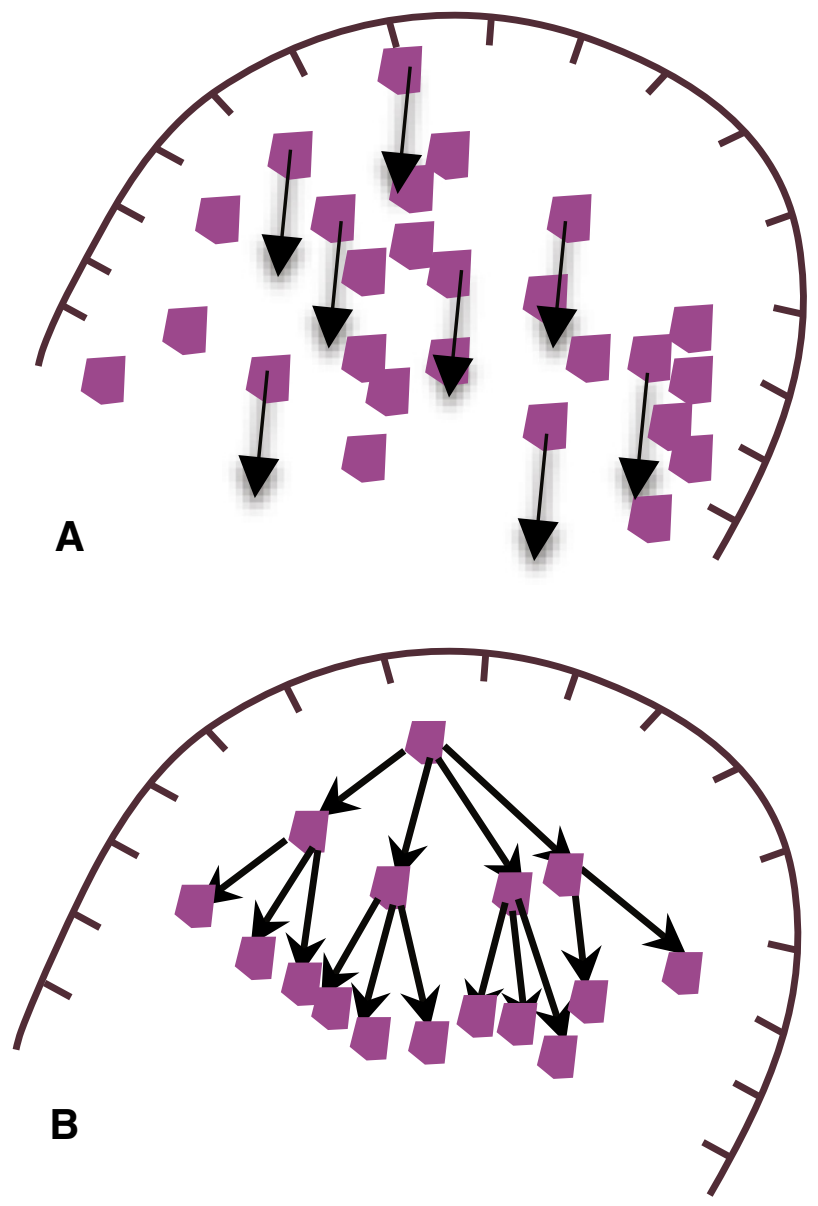

Fig. 15. Illustration of two modes of landslide initiation. A) The landslide is an aggregate of many small slope failures that initiate almost simultaneously within an area affected by ground shaking. B) The landslide is a cascading avalanche that propagates from one or a few points, similar to the rupture of an earthquake, or to the spread of a forest fire. As such, the final size of the landslide cannot be predicted at the onset of the event. The cumulative distribution of cascading avalanche processes is an inverse power law.

whose size distribution obeys an inverse power law (Densmore et al., 1998; Guzzetti et al., 2002; Malamud and Turcotte, 2006). Inverse power law distributions are the result of additive avalanche processes, in which the final size cannot be predicted at the onset of the disturbance. In terms of landslides, this process assumes that failure nucleates in one or more locations, spread to surrounding regions, and can coalesce to generate large failures. We argue that the observed power law distribution of landslide areas on land is determined by the size distribution of contingent hill slopes and is not indicative of the initiation process. For example, the cumulative distribution of hill slope areas with unique compass directions ("aspect" in Geographic Information System terminology) in the region affected by the M6.7 1994 Northridge earthquake has a similar inverse power law distribution with a similar exponent to the observed landslide distribution in the region (ten Brink et al., 2009a). Landslide distribution in southern California therefore appears controlled by the availability of slope areas to fail, not by the landslide process itself. In contrast, continental margins, and especially their lower slope regions provide fewer morphological constraints on the size of contiguous scars (ten Brink et al., 2009a) and their area distribution is therefore more a product of the initiation process.

\subsection{Tsunami generation by landslides}

Tsunamis are generated by submarine landslides through the vertical displacement of the sea floor during landslide movement. Near the source region, landslide tsunamis have a dipole type wave (Fig. 16). The region of excavation generates the negative polarity of the tsunami (depression wave) and the region of deposition generates the positive polarity (elevation wave). Small scale motion of the landslide is filtered through the water column as represented by Kajiura's (1963) tsunami Green's function $\frac{1}{\cos (k h)}$, where $h$ is the water depth and $k$ is the horizontal wavenumber of the vertical displacement profile. Because of watercolumn filtering, landslides and other processes with horizontal dimensions less than three times the water depth $(k h>1 / 3)$ generally do not cause significant tsunamis. The model shown in Fig. 16 is greatly simplified, however, in comparison to the known complexity of submarine landslides as described in Section 2.5 of this paper.

The primary source parameters for tsunami generation relate to both the geometry of the landslide and its dynamics. Aside from location, the geometrical parameters include the excavation and deposition length and width, head scarp height or maximum excavation depth, and maximum deposition thickness. To determine these parameters from historical case studies or mapped slides, it is necessary to estimate the pre-failure surface (ten Brink et al., 2006a; Chaytor et al., 2009). The primary dynamic tsunami generation parameters are the initial acceleration (greatest influence on the back-propagating tsunami) and the velocity of downslope movement. The latter controls the directivity of wave energy for the outgoing tsunami (Ward, 2001), with velocities approaching the phase speed of the tsunami ( $\sqrt{g h}$ in the long wavelength limit, where $g$ is the gravitational acceleration and $h$ is the water depth) having the greatest amplification. Debris flow mobility models (e.g., Imran et al., 2001; Elverhøi et al., 2010) can often constrain the dynamic parameters used for tsunami generation (Geist et al., 2009a; Locat et al., 2009). Smooth analytic functions for landslide tsunami generation that are compatible with hydrodynamic codes are provided by Lynett and Liu (2005). Alternatively, landslide tsunami generation has also been computed using center-of-mass approximations that combine the geometric and dynamic characteristics of landslides (Grilli and Watts, 2005).

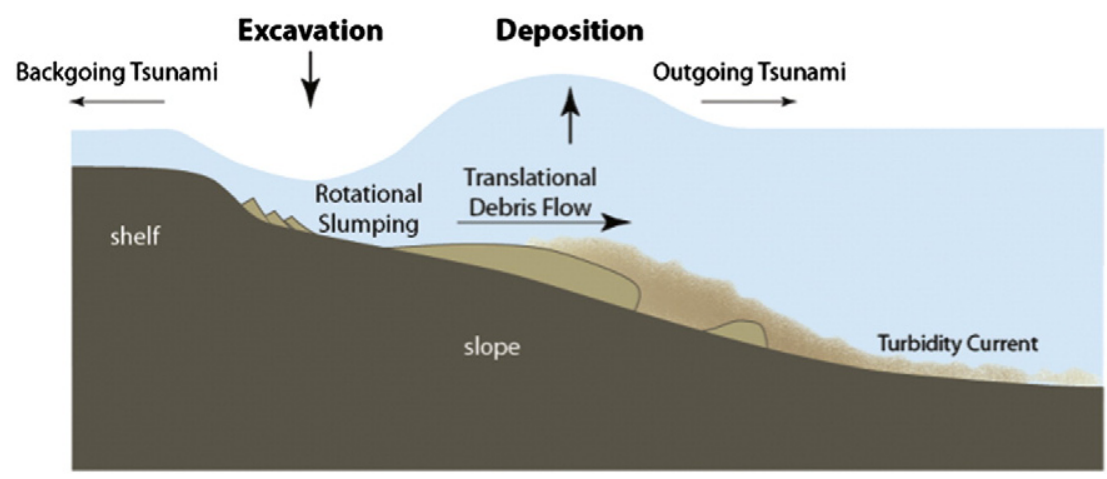

Fig. 16. Schematic of tsunami generation from a submarine landslide. 
In comparison to seismogenic tsunamis for which propagation can be described by the non-dispersive linear long wave equations, it is necessary to include the effects of both nonlinearity and dispersion for significant landslide tsunamis (Lynett and Liu, 2002). Liu (2009) provides a review of the applicable hydrodynamic equations for increasing levels of nonlinearity and dispersion. The combination of these two effects for propagation of landslide tsunami waves across a wide continental shelf, such as the Atlantic margin, produces interesting physics termed amplitude dispersion or fission (Wu, 1981; Lin, 2004; Lynett, 2008) as was simulated for the Currituck landslide tsunami (Geist et al., 2009a). The fission process results in a significant attenuation of landslide-generated tsunami waves relative to earthquake-generated tsunami waves, because of their smaller spatial dimensions and higher amplitude (cf., Korycansky and Lynett, 2005). For runup and inundation computations, it is also necessary to include nonlinearity and moving boundary conditions for both seismogenic and landslide tsunamis.

\section{Tsunami hazard from other local sources}

\subsection{Atmospheric disturbances (meteo-tsunamis)}

Meteo-tsunamis are atmospherically induced ocean waves with periods of a few minutes to a few hours (Monserrat et al., 2006). It is difficult to distinguish tsunamis generated by landslides from those generated by atmospheric disturbances, because of their similarities in wave period and the size of the affected area, as was the shown in the analysis of the June 13, 2013 tsunami (http://nctr.pmel.noaa.gov/ eastcoast20130613/) (see below). Meteo-tsunamis are generated when an atmospheric disturbance (pressure change) moves with a speed, $U$, that is similar to the ocean longwave phase speed, $c$. The passage of an atmospheric pressure disturbance, $\Delta P$, changes the sea surface amplitude, $\Delta \zeta$, by an amount $\Delta \zeta=\Delta P / \rho g$, where $\rho$ is the density of water. Typical pressure changes of fast-moving atmospheric disturbances are 100-500 Pa (Monserrat et al., 2006), therefore, the resulting sea surface height changes by $1-5 \mathrm{~cm}$. However, the sea surface amplitude, $\zeta$ greatly increases when the speed of the disturbance approaches the ocean longwave speed, according to the expression

$\zeta=\Delta \zeta /\left(1-(U / c)^{2}\right)$

(Proudman, 1929), termed Proudman resonance. In practice, the sea surface amplitude can increase 100 fold (Donn and McGuinness, 1960) giving rise to a destructive tsunami. The wave can be further amplified upon entering a harbor whose dimensions match the wave frequency. Meteo-tsunamis tend to occur on broad continental shelves and shallow platforms with water depth of $40-160 \mathrm{~m}$, because the typical speed of the atmospheric disturbances is $20-40 \mathrm{~m} / \mathrm{s}$ (Monserrat et al., 2006).

Destructive meteo-tsunamis have been reported from Croatia, the Balearic Islands, Japan, China, and Lake Michigan, to name a few places (Ewing et al., 1954; see references in Monserrat et al., 2006). Along the U.S. Atlantic coast, a $6 \mathrm{~m}$ high wave struck Daytona Beach, Florida, in 1992 (Churchill et al., 1995; Sallenger et al., 1995) and meteo-tsunamis were reported in Long Island Sound (Donn and Balachandran, 1969), and Boothbay Harbor, Maine (Vilibić et al., 2013). Pasquet et al. (2013) identified 9 events with wave heights of $0.4-1 \mathrm{~m}$ and dominant periods of $0.67-6 \mathrm{~h}$ on tide gauge records between 2006 and 2011 and attributed them to meteo-tsunamis.

A tsunami on June 13, 2013 caused severe harbor oscillations in Barnegat Bay New Jersey, Wickford Cove, Rhode Island, and Falmouth, Massachusetts. It was detected on DART buoy 44402 located on the lower continental slope east of Hudson Canyon, and in tide gauges extending along the Atlantic coast from Woods Hole, Massachusetts to Duck, North Carolina, and in Bermuda and Puerto Rico (http:// oldwcatwc.arh.noaa.gov/previous.events/06-13-13/index.php; http:// nctr.pmel.noaa.gov/eastcoast20130613/). This tsunami was first interpreted as a landslide at the head of the Hudson Canyon, but a multibeam sonar survey of the area by the NOAA ship Okeanos Explorer in July 2013 revealed nether fresh landslide scars and nor significant change in the bathymetry from previous surveys undertaken as little as one year earlier. A fast-moving squall that extended laterally more than $220 \mathrm{~km}$ crossed the New Jersey shore and moved eastward two hours prior to the detection of a tsunami on the DART buoy. Satellite radar shows this front propagating eastward toward the shelf edge (http://oldwcatwc.arh.noaa.gov/previous.events/06-13-13/index.php) with wind gusts recorded at a buoy at the head of the Hudson Canyon about 2 h later (http://nctr.pmel.noaa.gov/eastcoast20130613/). In reviewing the DART Buoy record, a previous smaller event on April 11, 2013 also registered on the DART buoy and several tide gauges (Christopher, Moore, Written Comm., 2013), but this event was not noticed by the public, because it occurred at night and not during a summer day.

Meteo-tsunamis can have a wider geographical extent than landslidegenerated tsunamis for two reasons: First, they are generated by a moving squall line, which can be hundreds of kilometers long. Long sources generate low-frequency waves, which propagate for longer distances. Second, the meteo-tsunami is reflected at the shoreline and at the shelf edge by topographic steps. The reflected angle follows Snell's law $\sin \left(\theta_{\mathrm{r}}\right)=\sin \left(\theta_{\mathrm{i}}\right) / \mathrm{F}_{\mathrm{r}}$, (Vennell, 2010; Pasquet and Vilibić, 2013) where $\theta_{\mathrm{r}}$ and $\theta_{\mathrm{i}}$ are the angles of the reflected and incident waves, respectively, and $\mathrm{F}_{\mathrm{r}}=\mathrm{U} / \mathrm{c}$. Many of the storms move oblique to the coast, and reflections from the shelf edge help push the wave farther down along the shelf. Shelf-edge reflections were noted on the tide gauge data from the April 11, 2013 event as second arrivals 2-4 h after the primary arrivals.

We compiled a database of atmospheric pressure disturbances along the U.S. Atlantic margin to investigate their frequency and characteristics. Data were compiled from the Automatic Surface Observing System data archive, the Storm Prediction Center Severe Weather Event archive and the National Hurricane Center Data Archive all maintained by NOAA. The database shows 191 squalls crossing the U.S. Atlantic shoreline eastward into the shelf during a 13-year period (04.08.200010.07.2013). The speed of these squalls upon crossing the shoreline was typically $13-22 \mathrm{~m} / \mathrm{s}$, and the pressure associated with their advance, typically rose by 100-400 Pa during periods of 30-90 min (Fig. 17). However, speeds of up to $35 \mathrm{~m} / \mathrm{s}$ and a pressure rise of $800 \mathrm{~Pa}$ were recorded. These squall lines were long (250-1000 km) and crossed the shoreline at different angles from perpendicular to nearly shore-parallel. The June 13, 2013 squall that caused the meteotsunami, moved at a speed of $22 \mathrm{~m} / \mathrm{s}$ when crossing the shoreline and accelerated to $27 \mathrm{~m} / \mathrm{s}$ over a weather buoy at the head of the Hudson canyon (http://nctr.pmel.noaa.gov/eastcoast20130613/). The pressure rise at the shoreline was $470 \mathrm{~Pa}$ and its duration was $50 \mathrm{~min}$. For this squall, the Proudman resonance was therefore expected to generate resonant long waves at water depths of 48-73 m midway across the shelf. Additional squalls have likely formed offshore and moved either parallel to shore or out to see never crossing the shoreline, and were therefore not detected by shore stations. Both the 2008 Boothbay Harbor event and the Daytona Beach 1992 event are not in our data base, because they were not identified onshore stations. Squalls over the Atlantic shelf are therefore much more frequent than previously thought, and should be considered in the assessment of tsunami hazards.

Another atmospheric disturbance affecting the shelf is hurricanes. Hurricanes typically move northward along the Atlantic margin shelf or make landfall. We compiled a list of 22 hurricanes that made landfall along the Atlantic coast between 1991 and 2012. The pressure drop associated with these hurricanes is typically 10 times that of the squalls but they move significantly slower (typically $\leq 12 \mathrm{~m} / \mathrm{s}$ ), and their pressure drop can last for days (Fig. 17). Thus, hurricanes generally do not 
A

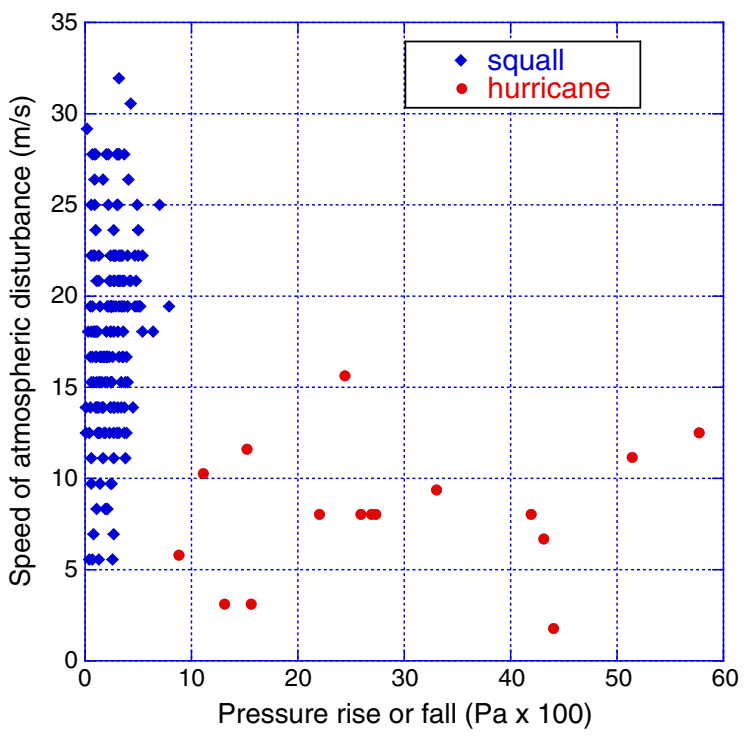

B
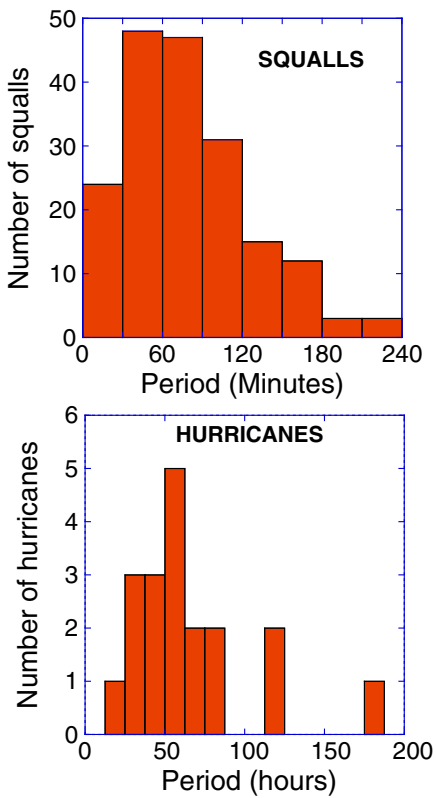

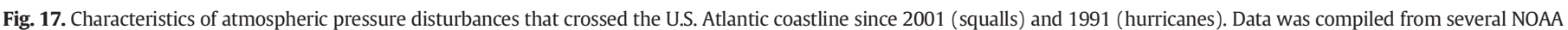

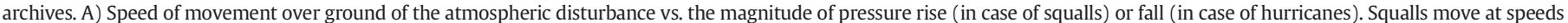

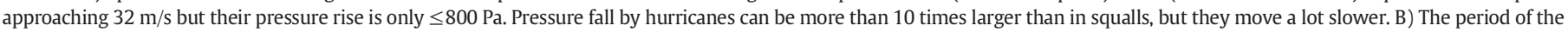

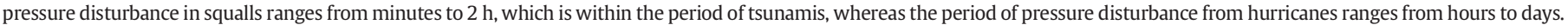

generate tsunami waves, only storm surge. Large waves advancing as walls of water toward the beach were described in association of the 1938 and 1944 hurricanes along the entire New Jersey coastline (Lockridge et al., 2002), but it is unclear if they were tsunami waves.

\subsection{Local earthquakes}

Earthquakes that occurred close to shore, such as the 1840 and the 1884 earthquakes near Philadelphia and the 1886 Charleston earthquake (Fig. 1) have locally produced tsunamis and seiches (Lockridge et al., 2002). The 1886 earthquake was also associated with a local tsunami in Jacksonville, FL, $290 \mathrm{~km}$ south of Charleston, South Carolina (Lockridge et al. (2002); Fig. 1).

\subsection{Events in the geological record}

Tsunami deposits are an important aid in tsunami hazard assessments, and in some areas, like the Washington-Oregon margin, they are the primary evidence for past tsunamis and their recurrence interval (Atwater and Hemphill-Haley, 1997). However, no such record exists along the U.S. Atlantic coast. A suggested $2300 \mathrm{yr}$ old tsunami deposit in Long Island (Goodbred et al., 2006) has not been confirmed. The only known tsunami deposits along the North American coast are in Newfoundland from the 1929 Grand Banks tsunami (Tuttle et al., 2004). Tuttle et al. (2004) compared these deposits to storm deposits and suggested criteria to distinguish between tsunami and storm deposits in coastal environments of the U.S. Atlantic coast. Finding pre-historic tsunami deposits along the U.S. Atlantic coast would be helpful for a tsunami assessment, however, such a task is made difficult by several factors: 1 ) the coastline is very long, 2 ) it has been modified in many places by intense anthropogenic changes, 3 ) it is subjected to frequent intensive storm activity, as was evidenced by the 2012 Hurricane Sandy, and 4) tsunami deposits laid prior to 6000 yr are likely covered by water due to the rapid sea level rise.

\section{Far-field tsunami sources: earthquakes, volcano collapse, and landslides}

\subsection{Earthquakes in the Azores-Gibraltar plate boundary}

The Azores-Gibraltar plate boundary is the source of the largest earthquakes in the 20th century as well as the largest historic earthquakes in the North Atlantic Ocean basin (Fukao, 1973; Buforn et al., 1988, 2004; Baptista et al., 2006). It was also the source of the great November 1, 1755 Lisbon earthquake with estimated magnitude Mw 8.5-9.0 (e.g., Johnston, 1996; Muir-Wood and Mignan, 2009). The tsunami wave, generated by the 1755 earthquake propagated across the Atlantic Ocean to the eastern Lesser Antilles and Brazil and to Newfoundland, Canada (Kozak et al., 2005; Roger et al., 2010). However, no reports were documented from cities (e.g., Boston, New York, Baltimore, Charleston and Savanna) and smaller towns that existed at the time along the U.S. Atlantic coast (Reid, 1914; Lockridge et al., 2002).

The source of the 1755 Lisbon earthquake remains elusive, and in fact, the location and nature of the plate boundary in the region are also poorly defined. Geodetic measurements predict that in the region southwest of the Iberian Peninsula, Africa should move at a rate of 4-5 mm/yr and a direction of $290^{\circ}$ relative to Eurasia (Nocquet and Calais, 2004) (Fig. 18). The plate boundary there might exhibit diffuse deformation over a zone several hundreds of kilometer wide. Two structures have been proposed as potential traces (SWIM; Zitellini et al., 2009 and PIAB; Barkan et al., 2009; Fig. 18). The prevailing orientations of ridges on the seafloor, active thrust faults (Zitellini et al., 2009) and compression axis of small and medium magnitude thrust earthquakes (Buforn et al., 2004; Stich et al., 2010) suggest NNW-SSE convergence (Fig. 18). The suggested dip of the 1755 rupture plane from back tracing the tsunami reported in coastal locations in the east (Baptista et al., 1998b) and west (Barkan et al., 2009) Atlantic is, however, perpendicular to the inferred convergence direction (Fig. 18). Alternatively, it is possible that the 1755 Lisbon earthquake was a manifestation of an active re-formation of the plate boundary in this area, analogous to the 


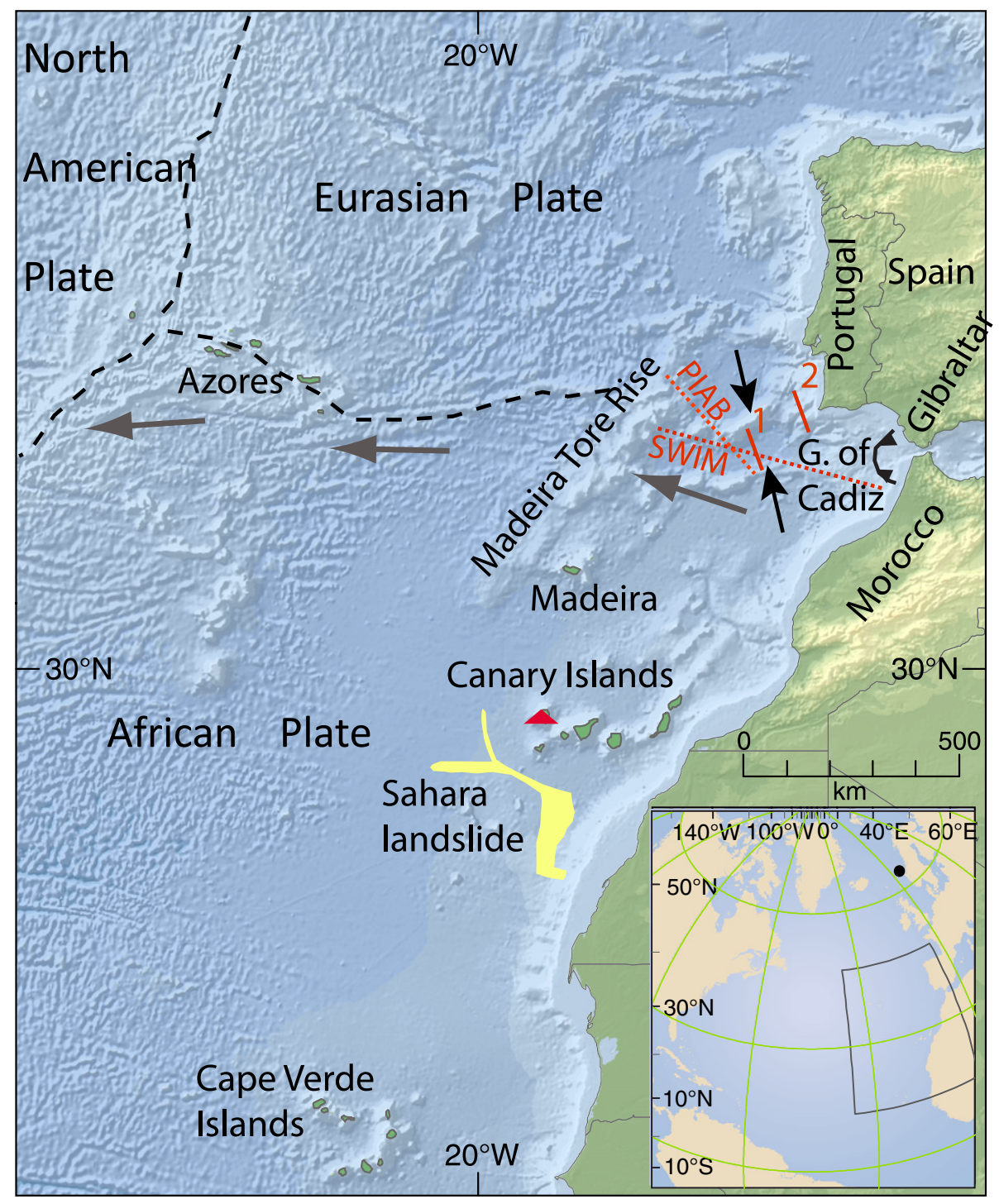

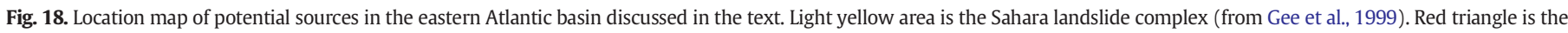

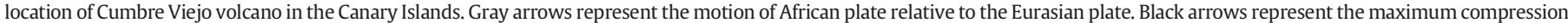

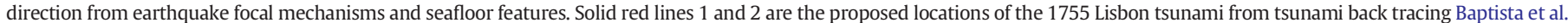

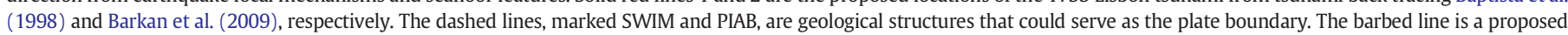
subduction zone by Gutscher (2004). The frame in the inset shows the location of the map. The black dot in the inset is the location of the Storegga slide.

April 11, 2012 M8.6 and M8.2 earthquakes that ruptured multiple faults on the ocean floor west of Sumatra, Indonesia (Ishii et al., 2013). Johnston (1996) and Stich et al. (2010) suggested that the 1755 Lisbon earthquake ruptured through a significant thickness of the mantle lithosphere and had therefore released significantly more energy than a crustal fault of a similar length.

The bathymetry of the eastern Atlantic Ocean is characterized by an irregular pattern of ridges, seamounts, and islands. These shallow bathymetric features scatter the long tsunami waves that travel across the Atlantic. Barkan et al. (2009) modeled the propagation of tsunami waves from 16 hypothetical sources in the eastern Atlantic Ocean and found that the shallow bathymetry would substantially attenuate tsunami waves reaching the U.S. Atlantic coast from most of these sources. However, sources located in the Gulf of Cadiz, where Gutscher (2004) proposed an east-dipping subduction of the African oceanic plate (Fig. 18), could generate significant tsunamis along the Florida and South Carolina coasts (Fig. 19a). Sources located west of the Madeira-Tore Rise, the westernmost bathymetric high in that region could also generate significant tsunamis along the Northeast and Mid-Atlantic coasts of the U.S. Earthquakes west of the Madeira-Tore
Rise including the M7.91975 have so far had only strike-slip focal mechanisms (Buforn et al., 1988) and plate kinematics predict pure strikeslip motion there. Strike-slip earthquakes seldom generate largeamplitude tsunamis. Fault strike in both the Gulf of Cadiz and west of the Madeira-Tore Rise needs to be oriented roughly N-S to generate the maximum wave height along the U.S. Atlantic coast.

\subsection{Earthquake in the Puerto Rico Trench}

The Puerto Rico Trench is the only subduction zone within the North Atlantic Ocean basin (Fig. 1). The North America Plate subducts there under the Caribbean Plate, but because the relative plate motion is

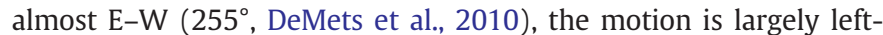
lateral strike slip with only a small component of perpendicular convergence (3-6 mm/yr). Nevertheless, as the M9.2 2004 Sumatra earthquake illustrated, highly oblique subduction zones are capable of generating devastating tsunamis if rupture during an earthquake has a large thrust component. Knight (2006), Geist and Parsons (2009) and Grilli et al. (2010) modeled the effect on the U.S. and Canadian Atlantic coasts from hypothetical tsunamis caused by M8.7-9.1 thrust earthquakes 

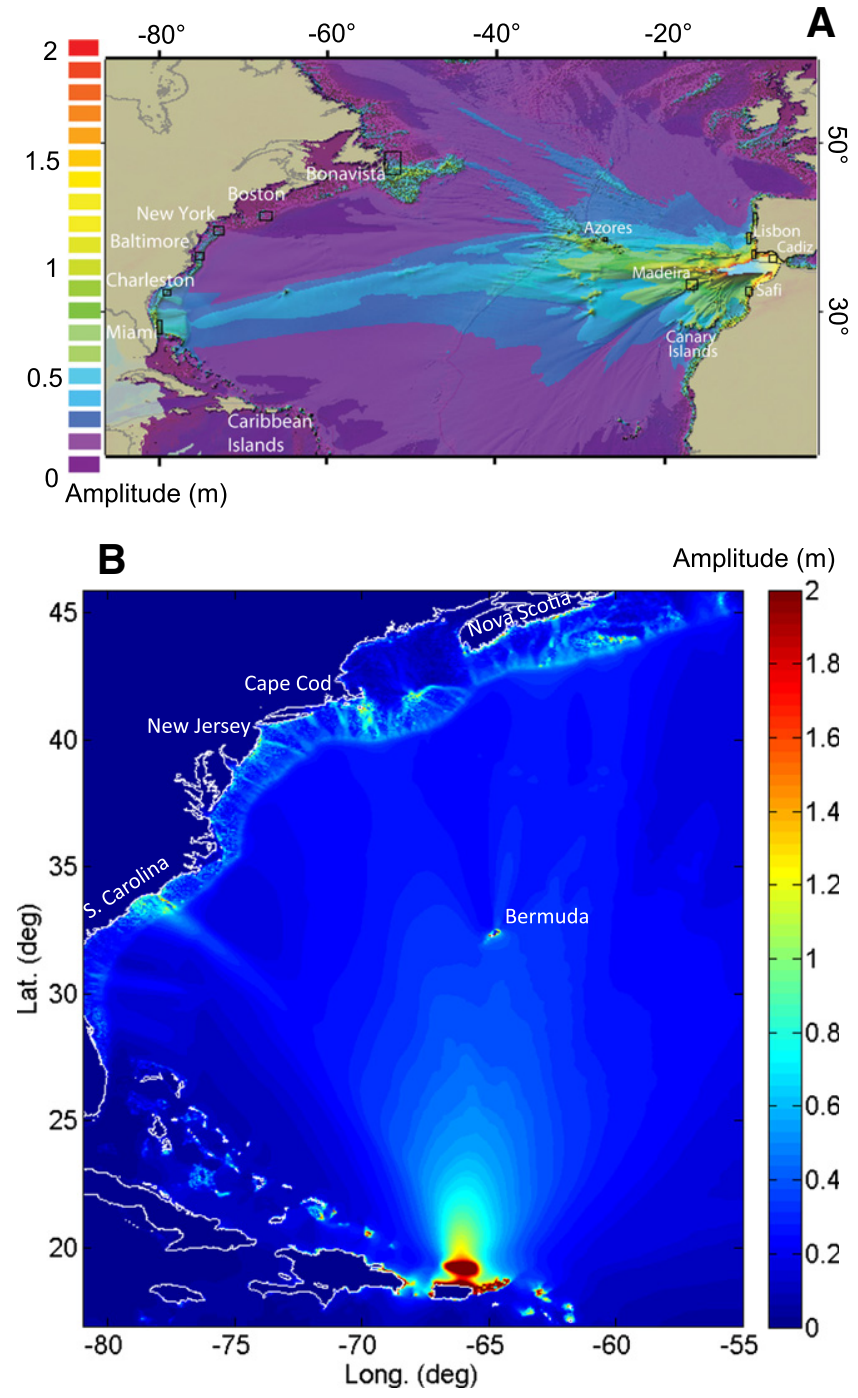

Fig. 19. Maximum wave amplitude from the propagation of two hypothetical tsunamis toward the U.S. Atlantic coast. A) From an M8.7 thrust earthquake located in the Gulf of Cadiz with a strike of $349^{\circ}$, that mimics subduction under the Strait of Gibraltar (see Barkan et al., 2009, for more details). B) From an M8.3 thrust earthquake in the Puerto Rico Trench with the following parameters: width $-150 \mathrm{~km}$, downdip length $-89 \mathrm{~km}$, top depth $-10 \mathrm{~km}$, strike $-90^{\circ}$, rake $-60^{\circ}$, dip $-21.5^{\circ}$, slip $-9.5 \mathrm{~m}$. Tsunami simulations were performed via the tsunami computational portal on the Arctic Region Supercomputing Center, using the program COMCOT.

with pure $\mathrm{N}-\mathrm{S}$ slip rupturing the entire trench length. Tsunami waves from these worst-case scenarios would propagate directly northward and would therefore affect more severely the coasts of Bermuda and Nova Scotia (wave amplitude of 6-8 m, Grilli et al., 2010) (Fig. 19b). However, the shape of the continental shelf also serves to increase wave amplitude toward Cape Cod, Massachusetts, Long Island, New York, and northern New Jersey, whereas the submarine Blake Outer Ridge focuses the wave toward the South Carolina coast. The maximum wave amplitudes in these locations are expected be $<3 \mathrm{~m}$ (New Jersey to Cape Cod) and $<2 \mathrm{~m}$ (South Carolina) (Grilli et al., 2010).

Large historical earthquakes in this subduction zone have only occurred west of $67.2^{\circ} \mathrm{W}$ (Dolan and Wald, 1998; ten Brink et al., 2011), although the recurrence interval for large earthquakes on the Puerto Rico Trench could be much larger than the written record because of the very slow convergence rate between the North American and Caribbean plates (Geist and Parsons, 2009). Paleo-tsunami deposits from two time periods were identified on the island of Anegada, located closest to the NE corner of the subduction zone (Atwater et al., 2012a, 2012b) (Fig. 1). Large coral boulders strewn as much as 500-600 m inland from Anegada's north shore were dated at medieval ages (1200-1450 AD; Atwater et al., 2012b). Extensive sand deposits in the western part of the island were dated as deposited after 1650 AD but prior to settlement of the island at $\sim 1800 \mathrm{AD}$ (Atwater et al., 2012b). These boulders and deposits were likely not emplaced by storms because of the low $(<2 \mathrm{~m})$ storm surge height along the north shore of the island (Wei et al., 2010). Tsunami models suggest that the older deposits could have been sourced in a tsunami from either the subduction zone or from normal faults within the downgoing plate. The later deposits could have been sourced by either the 1755 Lisbon tsunami or by sources similar to the older deposits (Wei et al., 2010). The lack of historical mention of a tsunami in Puerto Rico between 1650 and $1800 \mathrm{AD}$ precludes the source of that tsunami from being located on the subduction zone directly north of Puerto Rico (Wei et al., 2010).

A $300 \mathrm{~km}$ long portion of the Puerto Rico Trench centered north of Puerto Rico is deep $(8350 \mathrm{~m})$ and wide $(20 \mathrm{~km})$. This trench portion also has an unusually deep (7900 $\mathrm{m}$ ) forearc extending $50 \mathrm{~km}$ south of the trench, coincident with the lowest free-air gravity anomaly on Earth ( $-380 \mathrm{mGal}$ ) (ten Brink, 2005). The north shore of Puerto Rico consists of a tilted carbonate platform. Originally flat and formed near sea level, the platform's northern edge is now 4000 m deep and its southern edge is several hundreds of meters above sea level. Seismic reflection data show normal fault block on the subducting plate being rotated into the trench. ten Brink (2005) interpreted these unusual observations as evidence for a tear in the subducting North American Plate, which caused the trench and its vicinity to founder, and probably decreased the coupling along the subduction interface in the area. Additional observations support this interpretation - for example, GPS observations from Puerto Rico and the Virgin Islands show that these islands are moving northward toward the trench relative to the Caribbean Plate interior, which is the opposite direction to most subduction zone regions where elastic strain accumulates along the subduction interface (ten Brink and López-Venegas, 2012). Seismic activity in this segment of the trench is also unusual. Frequent earthquake swarms at depths of 70-150 km have predominantly normal and strike-slip mechanisms and may indicate active tearing of the slab (Meighan et al., 2013). Finally, global tomographic images show a missing slab in this part of the trench (ten Brink and Villaseñor, 2012).

Given the unusual phenomena observed in the central part of the trench, it is questionable whether a single rupture of the entire trench length (600-1100 km) producing an M9 earthquake could take place along the Puerto Rico Trench. Smaller earthquakes could certainly take place there but are unlikely to produce large enough tsunamis that will affect the U.S. Atlantic coast. Another earthquake source near the trench could however, generate tsunamis. The northern wall of the Puerto Rico Trench between $62^{\circ} \mathrm{W}$ and $66^{\circ} \mathrm{W}$ is characterized by grabens with up to $1500 \mathrm{~m}$ high escarpments (ten Brink, 2005). These escarpments are interpreted as normal faults (Fig. 1) produced by the bending of the downgoing North American plate as it enters the trench. Tsunamis have been produced in similar environments (e.g., 1933 Sanriku and 2009 Samoa earthquakes, Okal et al., 2010). The tsunami deposits on the island of Anegada, could have been deposited by tsunamis originating from a possible M8 earthquake along one of these normal faults.

\subsection{Earthquake in the northern Cuba fold-and-thrust belt}

An offshore fold-and-thrust belt, the Nortecubana fault system, rims the entire northern coast of Cuba (Fig. 1). Its central and western parts face south Florida, and provided it is tectonically active, could pose a significant tsunami hazard to Florida's Atlantic and Gulf of Mexico coasts. The Nortecubana fold-and-thrust belt marks the northern extent of south-dipping thrusts associated with the collision of the Greater Antilles volcanic arc against the stable continental margin of the Bahama Platform (Draper and Barros, 1994). Deformation on this fault system took place prior to and during the Eocene (Masaferro et al., 
1999; Saura et al., 2008), before the North American-Caribbean plate boundary jumped to Cayman Trough south of Cuba (e.g., Draper and Barros, 1994). Cuba had been part of the North American Plate since the Eocene, and rigid plate tectonics predicts no further deformation across Cuba. Stratigraphic analysis of one of the anticlines within this belt suggests, however, that some deformation may have continued into the Neogene and perhaps to the present day (Masaferro et al., 1999). Campaign GPS measurements show Guantanamo, Cuba, to be moving northward relative to stable North America by $<3 \mathrm{~mm} / \mathrm{yr}$, but this motion could be interpreted to be the result of accumulating elastic strain on the nearby Oriente fault (Dixon et al., 1998). Two shallow crustal earthquakes with an undetermined focal mechanisms occurred on the Cuban coast on January 9 (M5.1) and February 5, 2014 (M4.3) (Fig. 1). The rupture could have occurred on either the Nortecubana fold-and-thrust belt or on secondary NE-SW-oriented fault. A moderate $(\mathrm{M} \sim 6$ ) earthquake rocked NW Cuba in 1880 near Pinar Fault (Fig. 1), a possibly-active fault located onshore and sub-parallel to the Nortecubana belt (García et al., 2003). No tsunamis were generated from either earthquake. More research is needed to determine the hazard potential of the Nortecubana fault system.

\subsection{Volcano collapse in the Canary archipelago}

Ward and Day (2001) have suggested that an imminent flank collapse of the Cumbre Vieja volcano in the Canary Islands (Fig. 18) could generate a high-amplitude (10-25 m) tsunami along parts of the U.S. Atlantic coast. Various aspects of this suggestion have since been critically evaluated. We briefly review two of these aspects: First, tsunami amplitude scales with the landslide volume and Ward and Day (2001) assumed a large volume of $500 \mathrm{~km}^{3}$. Fieldwork, laboratory tests, and slope stability analysis reduced this estimate to between 38 and $68 \mathrm{~km}^{3}$ (Abadie et al., 2012). Turbidity records from eight Canary Island landslides suggest multistage failure for each landslide with individual volumes $<100 \mathrm{~km}^{3}$ (Hunt et al., 2013a). The recurrence rate of flank-collapse landslides in the Canary Islands is estimated at $\sim 200,000 \mathrm{yr}$ from the ages of major volcanoclastic turbidite deposits (Hunt et al., 2013b and references therein). Second, Ward and Day (2001) model assumptions maximized the predicted far-field tsunami from this source because it used linear propagation of shallow water waves, which describe geometric spreading and dispersive effects but not the effects of nonlinearity, wave breaking, and the compressibility of slide material. Subsequent analysis have utilized Navier-Stokes models incorporating compressible and incompressible multi-materials for wave generation and higher-order wave equations to describe transoceanic propagation (e.g., Mader, 2001; Gisler et al., 2006; Løvholt et al., 2008; Zhou et al., 2011; Abadie et al., 2012). These models predict tsunami wave heights of tens and even hundreds of meters in the near field (i.e., the coasts of the Canary Islands), but maximum wave heights along the US Atlantic coast of $<10 \mathrm{~m}$, even for the large landslide volume, suggested by Ward and Day (2001). A wave height $<10 \mathrm{~m}$ is $2-3$ times or more smaller than the maximum height predicted by Ward and Day (2001).

\subsection{Volcano collapse in the Azores and Cape Verde Islands}

The tsunamigenic potential of landslides initiated on the flanks of the islands of the Azores and Cape Verde archipelagos (Fig. 18) is not well constrained. Evidence for subaerial and submarine slope failures was documented on the flanks of the islands of the Cape Verde (Day et al., 1999; Le Bas et al., 2007; Masson et al., 2008) and Azores (Mitchell, 2003; Hildenbrand et al., 2012; Mitchell et al., 2012) archipelagos, although the level of instability, linkage to volcanic processes, and age of individual failures are highly uncertain for both regions. Radar interferometry, GPS networks and field analysis have confirmed the presence of active, but most likely gradual, slumping along the subaerial southern flank of Pico Island in the Azores (Hildenbrand et al., 2012;
Mitchell et al., 2012). Evidence of adjacent submarine debris fields is limited and open for debate (e.g., Mitchell et al., 2012). Debris fields are well developed along the submerged flanks of most of the islands of the Cape Verde archipelago, some of which may have mobilized up to $160 \mathrm{~km}^{3}$ of material (Masson et al., 2008). Based on overprinting of landslide scars by volcanic flows, sedimentation and canyon erosion, Masson et al. (2008) postulated that the ages of landslides on the flanks of the islands of Fogo, Santo Antao, Sao Vincente, and Sao Nicolau to be between 80,000 yr and more than 5.8 Myr. Evidence of renewed flank instability on the island of Fogo has been reported by Day et al. (1999b) but Masson et al. (2008) considers this to most likely produce a future east-directed landslide capable of generating a destructive tsunami in the near-field and along the coast of West Africa rather than the Atlantic coast of the U.S.

\subsection{Northeastern Atlantic Ocean Submarine Landslides}

Numerous submarine landslide scars and mass transport deposits have been identified along the European and African coasts of the Atlantic Ocean (Canals et al., 2004; Lee, 2009). The Storegga (Norway) (inset in Fig. 18) and Sahara (Africa) (Fig. 18) slides are two of the largest and most well studied from the East Atlantic margins. The Storegga Slide is a composite failure with seven landslides occurring during the past $0.5 \mathrm{Myr}$ (Solheim et al., 2005, and references within). The latest and largest landslide is dated at $8200 \mathrm{yr}$ BP (Haflidason et al., 2005) with a total volume of $2500-3000 \mathrm{~km}^{3}$. Modeling of the tsunami generated by the Storegga Slide (Bondevik et al., 2005) shows significant local wave heights $(>20 \mathrm{~m}$ ) that diminish with distance from the source consistent with coastal inundations identified by onshore tsunami deposits in Norway, Iceland, Scotland, and the Shetland Islands. Transoceanic propagation models from the Storegga Slide have not been carried out, but due to attenuation of waves over the $>6000 \mathrm{~km}$ propagation distance and due to scattering by intervening islands, tsunami wave heights along the U.S. Atlantic coast would likely be small.

The Sahara Slide is estimated to have mobilized approximately $600 \mathrm{~km}^{3}$ of material (Embley and Jacobi, 1977) depositing it over a run-out distance of more than $900 \mathrm{~km}$ (Georgiopoulou et al., 2010). Estimates of the age of the slide are 45 to $59 \mathrm{Kyr}$ (Georgiopoulou et al., 2010), with a subsequent smaller debris flow overprinting part of the deposit approximately 2000 yr BP (Embley, 1982; Georgiopoulou et al., 2009). The tsunami generation potential of the Sahara Slide is thought to be low due to the slow moving nature of the slide (Georgiopoulou et al., 2010) and the depth of the headwall (1900 m; Krastel et al., 2012), but modeling of its impact on the U.S. Atlantic coast has not been carried out.

\section{Tsunami hazard assessment}

\subsection{Deterministic approaches}

Hazard assessment for tsunamis can generally take two forms: deterministic and probabilistic. Deterministic assessment involves evaluating the source parameters specific to tsunami generation then using a numerical propagation and inundation model that is appropriate for the characteristics of the generated waves (see Section 2.7). Several review papers have described the salient source parameters for tsunami generation by earthquakes (Geist, 1999; Satake, 2007). For landslide tsunamis, there is less of a consensus on which source parameters to include, owing to the complexity of the tsunami generating process (e.g., Geist et al., 2009b; Harbitz et al., 2013).

Although the procedure for developing a deterministic landslide assessment from historical case studies or mapped landslides is straightforward there is less certainty on how to proceed with a worst-case or maximum credible landslide tsunami hazard assessment. One approach is to use the maximum mapped landslide in a region with similar geologic and failure conditions (expected horizontal 
acceleration, pore pressure, etc.). Another more conservative approach is to use the maximum individual source parameters (scarp height, run-out length, etc.) determined from all the slides in a given region. However, the 1929 Grand Banks landslide shows that a very large tsunamigenic landslide can leave no specific indicator for a single event (e.g., Mosher and Piper, 2007) complicating the determination of a maximum individual source. One can also consider the potential for landslides that are larger than those that are mapped. A landslide size distribution (Section 2.4 of this paper) can be used to guide that choice of maximum possible landslide. An example of this type of approach for tsunami hazard assessment along the north shore of Puerto Rico is described by ten Brink et al. (2006a).

\subsection{Probabilistic approaches}

In contrast to deterministic analysis where a single hazard value is produced, probabilistic tsunami hazard analysis (PTHA) determines the hazard over a range of probabilities or mean return times (Geist and Parsons, 2006). The hazard from a large number of possible sources is aggregated to develop a tsunami hazard curve that plots runup $(R)$ or other hazard variable along the horizontal axis and frequency or probability of exceedance $(P)$ along the vertical axis (Fig. 20). Typically, a design probability is specified from the outset (e.g., $1 \%$ annual probability or the "100-year" flood for flood-insurance rate maps) and an exceedance runup value is determined at a particular location (Fig. 20A). This approach can be expanded to include many locations in a given region to produce a probabilistic inundation map for a given design probability (González et al., 2009). Optionally, one may have a risk tolerance level (e.g., the overtopping height of a sea wall) with the objective of determining the probability of exceedance for a particular runup or wave height (Fig. 20B).

Multiple sources of uncertainty related to source parameters and numerical models of tsunamis are considered in PTHA (see also Harbitz et al., 2013). Epistemic uncertainty (uncertainty due to incomplete knowledge and data about various model parameters, characterizations and assumptions) can be reduced by the collection of new data. Aleatory uncertainty relates to the natural or stochastic uncertainty inherent in a physical system and cannot be reduced. A single hazard curve is obtained by integration over the aleatory uncertainties and over all possible sources. A large number of hazard curves are obtained for different branches of a logic tree representing the epistemic uncertainty. The final hazard curve is represented by the mean, median, or other specified fractile of all hazard curves. A diagram showing the general PTHA procedure to compute tsunami hazard curves for all tsunami sources is shown in Fig. 21.

Significant sources of uncertainty are first identified (top row). Consideration should be given on the expected effect each uncertainty has on the hazard curve at the design probability or risk tolerance level of interest. Typically, a panel of experts is assembled to make this determination for both aleatory and epistemic uncertainty (the latter, to be included in a logic tree). The sequential procedure for each branch of the logic tree is given in the middle row of Fig. 21. First, the distribution of source parameters is determined. Typically, a parameter representing the overall size of the source (e.g., seismic moment for earthquakes, volume or area for landslides) and its distribution are defined. Size distributions for numerous submarine landslides are shown in Fig. 12 and for earthquakes along seismic zones in the Atlantic Ocean in Geist and Parsons (2009).

Other source parameters are scaled with respect to the size parameter. Importantly for PTHA, a relationship between the tsunami source size and long-term rate of occurrence must be established. Second, a probability model for the occurrence of the sources in time is chosen based on event ages (cf. Section 2.3 in this paper). Often, sources are assumed to occur according to a random Poisson process with an exponential distribution of inter-event or recurrence times (Geist et al., 2009b). However, alternative probability models can be considered in the logic-tree framework, such as quasi-periodic and temporally clustered models (Geist et al., 2013). Third, for each source used in the PTHA analysis, a tsunami generation, propagation, and runup/ inundation model is used to determine the wave height or other hazard variable at a particular coastal site. The fourth and final step aggregates the probability of tsunami wave height exceedance from all sources. Several references describe the aggregation procedure for PTHA (Rikitake and Aida, 1988; Geist and Parsons, 2006; Annaka et al., 2007; Geist et al., 2009b). Throughout this process, the entire logic tree is constructed, keeping track of each branch (bottom row of Fig. 21). After all hazard curves for each branch of the logic tree are estimated, a mean, median, or some other fractile is chosen as the final hazard curve.

There are large uncertainties for each of the components of PTHA for the U.S. Atlantic margin, given the sparse information on submarine landslides. The largest uncertainty is most likely related to the longterm rate of landslide occurrence. There is also considerable uncertainty in defining the probability distributions for each of the landslide parameters that are important for tsunami generation (for example, slide volume, thickness, speed). State-of-the-art numerical modeling of tsunami waves can be used to calculate runup associated with particular
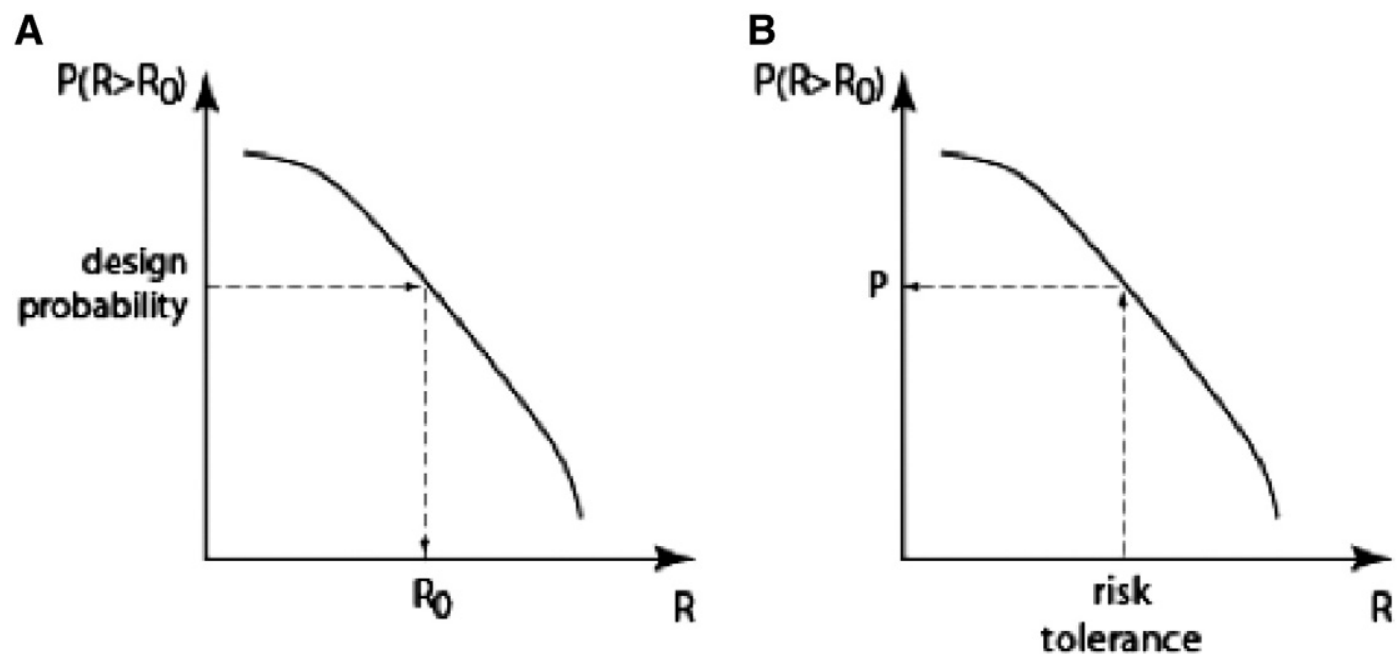

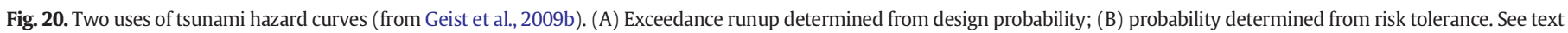
for additional details. 


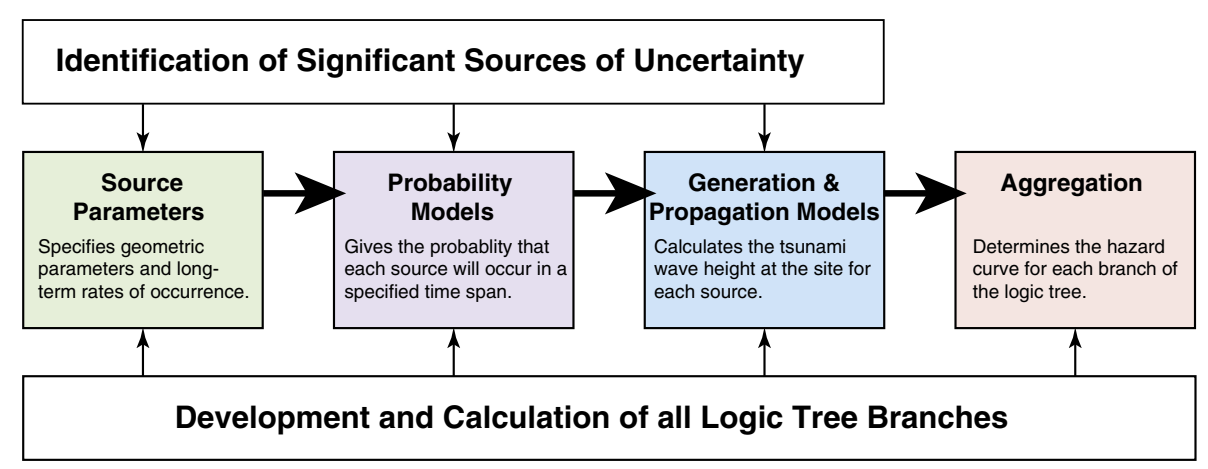

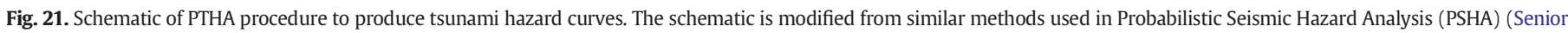
Seismic Hazard Analysis Committee (SSHAC), 1997). See text for additional details.

submarine landslide parameters as described for the deterministic approach. Calculating the tsunami hazard curve, however, requires many runs for each source location and variation in volume, duration, excavation depth, deposit thickness, etc., for each source, thus requiring substantial computational resources. Initial experiments and additional challenges in including submarine landslides into PTHA are described in a recent workshop report (Geist and ten Brink, 2012).

\section{Discussion}

Tsunamis along the U.S. Atlantic margin are rare events, because the margin is located in a region of slow tectonic activity where potential earthquake-generated landslides that might cause tsunamis are infrequent. These conditions, which exist also in other passive margins around the world, present a challenge to the deterministic and probabilistic assessments of extremely rare events. In the following sections, we focus on several questions, where future answers can help quantify and improve these assessments.

\subsection{Is landslide distribution uniform in space and time?}

The observed landslide distribution does not appear to be uniform in space and is concentrated in several distinct regions along the margin. Twichell et al. (2009) map of the fluvial and glacial portions of the U.S. Atlantic margin shows that $33 \%$ of the glacial margin between the New England/Georges Bank and Southern New England is covered by landslide scars and deposits, compared with $16 \%$ of the area in the fluvial portion between Hudson Canyon and Cape Hatteras and only $13 \%$ in the salt-dome area south of Cape Hatteras. In the glacial segment of the margin, two areas in particular have a high density of landslide scars, Southern New England and Georges Bank. In the fluvial segment of the margin, Baltimore Canyon and the Currituck area have the highest density of landslide scars. Whether the observed distribution reflects the distribution of seismic activity along the margin (Section 2.5) or whether it is a function of available sediments and depositional processes, is presently not resolved. The glacial margin may have more landslides because of the larger volume of sediment available on the slope, but the present offshore seismicity, however, is also concentrated in the same region (http://earthquake.usgs.gov/earthquakes/ search/ accessed 01.30.2014). The Currituck slide is likely located seaward of a shelf-edge delta (Fig. 4) and the Baltimore Canyon area may have been fed by the ancestral Delaware River (Twichell et al., 1977) (Fig. 1). The thickness of Quaternary sediments is likely controlled also by the physiography of the pre-Pleistocene margin (Brothers et al., 2013a, Section 2.1.1), which could have limited the accommodation space in parts of the margin and would have promoted sediment bypass to the deeper parts of the margin. Better monitoring of the seismic activity along the margin, and better mapping of buried shelf-edge deltas and the thickness of Quaternary sediments will help clarify the factors controlling the spatial distribution of landslides.

The available ages of landslides along the U.S. Atlantic margin fall within the Late Pleistocene ( 10,000-25,000 years BP) (Section 2.3.2). However, not enough dates are available from this margin to derive a statistically significant conclusion about the temporal distribution of landslides. Urlaub et al. (2013) has shown that well-dated landslides world-wide are distributed randomly in time with landslide dates from river fan systems being clustered between 5000 and 25,000 years BP. Any compilation is inherently biased toward younger ages, because older landslides may be removed by younger landslides or covered by sediments. Analysis of landslides encountered in boreholes in the salt province of the Gulf of Mexico indicates a random (time independent Poisson) or a quasi-periodic process (Geist et al., 2013).

\subsection{Are areas that have already failed, expect to fail again?}

Sediment supply appears to play an important role in slope failures in the fluvial and glacial portions of the margin (Section 2.2.1). With significant decrease in sediment supply to the margin since the middle Holocene, hardly any younger sediments have been deposited on the margin. To assess the probability of future landslides, we need to evaluate whether all the sediments that were available to fail have already failed. The answer to this question likely depends on the spatial distribution of large earthquakes since the mid-Holocene. If earthquakes were distributed such that strong seismic acceleration affected the entire margin, then no more landslides are expected in the glacial and fluvial zones until more sediments are added to the margin. The predecessors of the Storegga slide have indeed occurred roughly every $100 \mathrm{ky}$ following the glacial-interglacial cycles (Solheim et al., 2005). On the other hand, if most landslide ages along the Atlantic margin are preHolocene (Section 2.3.2) then there may be suffcient sediments still available to fail on the Atlantic margin. With the exception of the upper slope of the Southern New England margin, the thickness of Quaternary sediments along the shelf edge and on the lower slope is fairly uniform (Poag, 1992; Holocene thickness was not mapped). Landslide scars however, do not cover the entire lower slope, indicating that failure is perhaps limited by the location of large earthquakes. An evaluation of earthquake recurrence along the margin is therefore critical to the assessment of future landslides.

This discussion applies only to the fluvial and glacial portions of the margin. Carbonate margins will likely fail where weaknesses (such as fissures) are developed by rock dissolution and when earthquakes occur (ten Brink et al., 2009a). Failure rate in the salt diaper province will depend on the rate of salt movement, as may have been the case for the Cape Fear slide (Hornbach et al., 2007). 


\subsection{How do tsunamis initiate from aggregate failures?}

If a landslide is in fact an aggregate of many smaller landslides that fail simultaneously or almost simultaneously over a continuous or discontinuous region (Section 2.6), how is the slide energy being transferred to the water column? The 1929 Grand Banks landslide shows that a spatially distributed aggregate failure is capable of generating tsunamis. The aggregate failure moved downslope and coalesced into thick debris flows, which ultimately turned into turbidity flows (Piper et al., 1999). When during this progression was the tsunami generated is, however, unclear. Laboratory simulations of tsunamis, used to benchmark tsunami models, typically involve a rigid sliding block (Enet and Grilli, 2007). Some numerical models implement a moving-boundary algorithm in which the seafloor changes its shape over a finite time to produce excavation in the upper part of the slope and deposition farther down (Lynett and Liu, 2002). Haugen et al. (2005) explored the effect of an idealized retrogressive slide with varying number of blocks and time lags of motion on the amplitude and dispersion of waves. Harbitz et al. (2006) showed that retrogressive failures of sub-events often reduce the amplitude of the corresponding tsunamis, however, there are conditions where tsunami amplitude can increase over the predicted amplitude from a single failure event. The physical process for transferring potential energy to the water column, when a landslide is composed of coalescing, aggregate failures, such as occurred in the 1929 Grand Banks landslide is presently unclear. Accurate modeling of realistic submarine landslides remains a challenge.

\section{Conclusions}

At present we can offer several tentative conclusions regarding the various tsunami sources with potential to affect the U.S. Atlantic coast.

1. Dated landslides along the Atlantic margin are generally between 10,000 and 25,000 years, but the number of dated landslides is too small to derive a probabilistic distribution. Global compilation of landslide dates indicates a random (Poisson) temporal distribution.

2. The spatial distribution of landslides along the margin is expected to be uneven and to depend on the distribution of seismic activity along the margin and on the spatial distribution of Pleistocene sediment supply on the margin.

3. The contribution of other pre-conditioning factors such as weak sedimentary layers and pore overpressure cannot be assessed. We do not see evidence that gas hydrate dissociation contributes to the generation of landslides along the U.S. Atlantic margin, despite recent suggestions in the literature. Bottom stress by the deep Western Boundary Undercurrent does not appear to contribute to slope failure.

4. Analyses of landslide statistics along the fluvial and glacial portions of the margin indicate that most of the landslides are translational, were probably initiated by seismic acceleration, and failed as aggregate slope failures.

5. Large ( $\leq$ M7.5) earthquakes close to the shoreline are not expected to cause landslides on the continental slope but may cause damaging seiches and embankment collapse within bays and rivers of the U.S. Atlantic coast.

6. Estimates of the mean recurrence interval of earthquakes along the continental slope are easier to obtain than those of landslides and may provide estimates for the mean recurrence interval of landslide along the margin.

7. Meteo-tsunamis may present a tsunami hazard all along the coast, given the wide and shallow shelf and the high frequency of the generating storms.

8. Far-field earthquake sources are less likely to constitute a tsunami hazard to the margin than landslides and meteo-tsunamis. Modeling suggests that earthquake sources southwest of the Iberian Peninsula will only affect the U.S. Atlantic Coast if they are located within the Gulf of Cadiz or west of the Tore-Madeira Rise. It is probably unlikely that subduction earthquakes from the Puerto Rico Trench will produce tsunamis capable of affecting the U.S. Atlantic Coast. More information is needed to evaluate the seismic potential of the northern Cuba fold-and-thrust belt.

9. The mean recurrence of volcano flank collapses in the Canary Islands is probably 200,000 years, their volumes may be smaller than previously estimated and their energy dispersed more quickly with distance. Information to evaluate the magnitude and frequency of flank collapse from the Azores Islands is limited.

10. Both deterministic and probabilistic methods to evaluate the tsunami hazard from the margin have been developed but their implementation requires better data than is currently is available.

\section{Acknowledgment}

The work was funded by the U.S.-NRC Job Code V6166: Tsunami Landslide Source Probability and Potential Impact on New and Existing Power Plants. We thank Matt Gove for compiling the storm data in Fig. 17, and Debbie Hutchinson, David Tappin, editor David Piper, and an anonymous reviewer for their helpful comments.

\section{References}

Abadie, S.M., Harris, J.C., Grilli, S.T., Fabre, R., 2012. Numerical modeling of tsunami waves generated by the flank collapse of the Cumbre Vieja Volcano (La Palma, Canary Islands): tsunami source and near field effects. Journal of Geophysical Research: Oceans 117, C05030.

Alperin, M.J., Suayah, I.B., Benninger, L.K., Martens, C.S., 2002. Modern organic carbon burial fluxes, recent sedimentation rates, and particle mixing rates from the upper continental slope near Cape Hatteras, North Carolina (USA). Deep Sea Research Part II: Topical Studies in Oceanography 49, 4645-4665.

Andrews, B.D., Chaytor, J.D., ten Brink, U.S., Brothers, D.S., Gardner, J.V., 2013. Bathymetric terrain model of the Atlantic Margin for marine geological investigations. U.S. Geological Survey Open-File Report 2012-1266.

Annaka, T., Satake, K., Sakakiyama, T., Yanagisawa, K., Shuto, N., 2007. Logic-tree approach for probabilistic tsunami hazard analysis and it applications to the Japanese Coasts. Pure and Applied Geophysics 164, 577-592.

Atwater, B.F., Hemphill-Haley, E., 1997. Recurrence intervals for great earthquakes of the past 3,500 years at northeastern Willapa Bay, Washington. United States Geological Survey Professional Paper 1576, 1-108.

Atwater, B.F., ten Brink, U.S., Buckley, M., Halley, R.S., Jaffe, B.E., López-Venegas, A.M., Reinhardt, E.G., Tuttle, M.P., Watt, S., Wei, Y., 2012a. Geomorphic and stratigraphic evidence for an unusual tsunami or storm a few centuries ago at Anegada, British Virgin Islands. Natural Hazards 63, 51-84.

Atwater, B.F., ten Brink, U.S., Feuillet, N., Fuentes Figueroa, Z., Halley, R.B., Tuttle, M.P., Wei, Y., Weil Accardo, J., 2012b. Geologic evidence for a medieval tsunami with an eastern source along the Puerto Rico Trench. AGU Fall Meeting, T41A-2566.

Baptista, M.A., Miranda, P.M.A., Miranda, J.M., Mendes Victor, L., 1998. Constraints on source of the 1755 Lisbon tsunami inferred from numerical modelling of historical data on the source of the 1775 Lisbon tsunami. Journal of Geodynamics 25, 159-174.

Baptista, M.A., Miranda, J.M., Luis, J.F., 2006. In search of the 31 March 1761 earthquake and tsunami sources. Bulletin of Seismological Society of America 96, 713-721.

Barkan, R., ten Brink, U.S., Lin, J., 2009. Far field tsunami simulations of the 1755 Lisbon earthquake: implications for tsunami hazard to the US East Coast and the Caribbean. Marine Geology 264, 109-122.

Bondevik, S., Løvholt, F., Harbitz, C., Mangerud, J., Dawson, A., Inge Svendsen, J., 2005. The Storegga slide tsunami-comparing field observations with numerical simulations. Marine and Petroleum Geology 22, 195-208.

Booth, J.S., O'Leary, D.W., 1991. A statistical overview of mass movement characteristics on the North American Atlantic outer continental margin. Marine Georesources \& Geotechnology 10, 1-18.

Booth, J.S., O'Leary, D.W., Popenoe, P., Danforth, W.W., 1993. U.S. Atlanticslope landslides: their distribution, general attributes, and implications. In: Schwab, W.C., Lee, H.J., Twichell, D.C. (Eds.), Submarine landslides: selected studies in the U.S. Exclusive Economic Zone. USGS Bulletin no. 2002, pp. 14-22.

Brothers, D.S., ten Brink, U.S., Andrews, B.D., Chaytor, J.D., 2013a. Geomorphic characterization of the US Atlantic continental margin. Marine Geology 338, 46-63.

Brothers, D.S., ten Brink, U.S., Andrews, B.D., Chaytor, J.D., Twichell, D.C., 2013b. Geomorphic process fingerprints of submarine canyons. Marine Geology 337, 53-66.

Brothers, D.S., Luttrell, K.M., Chaytor, J.D., 2013c. Sea-level-induced seismicity and submarine landslide occurrence. Geology 41, 979-982.

Brothers, D.S., Ruppel, C., Kluesner, J.W., ten Brink, U.S., Chaytor, J.D., Hill, J.C., Andrews, B.D., Flores, C., 2014. Seabed fluid expulsion along the upper slope and outer shelf of the U.S. Atlantic continental margin. Geophysical Research Letters 41 (2013GL058048).

Buforn, E., Udías, A., Mézcua, J., 1988. Seismicity and focal mechanisms in south Spain. Bulletin of the Seismological Society of America 78, 2008-2224. 
Buforn, E., Bezzeghoud, M., Udĺas, A., Pro, C., 2004. Seismic sources on the Iberia-African Plate boundary and their tectonic implications. Pure and Applied Geophysics 161, 623-646.

Bunn, A.R., McGregor, B.A., 1980. Morphology of the North Carolina continental slope, western North Atlantic, shaped by deltaic sedimentation and slumping. Marine Geology 37, 253-266.

Canals, M., Lastras, G., Urgeles, R., Casamor, J., Mienert, J., Cattaneo, A., De Batist, M., Haflidason, H., Imbo, Y., Laberg, J., 2004. Slope failure dynamics and impacts from seafloor and shallow sub-seafloor geophysical data: case studies from the COSTA project. Marine Geology 213, 9-72.

Cashman, K., Popenoe, P., 1985. Slumping and shallow faulting related to the presence of salt on the continental slope and rise off North Carolina. Marine and Petroleum Geology 2, 260-271.

Chaytor, J.D., Twichell, D.C., ten Brink, U.S., Buczkowski, B.J., Andrews, B.D., 2007. Revisiting submarine mass movements along the U.S. Atlantic margin: implications for tsunami hazards. In: Lykousis, V., Sakellariou, D., Locat, J. (Eds.), Submarine Mass Movements and Their Consequences. V. Springer, pp. 395-403.

Chaytor, J., ten Brink, U.S., Solow, A.R., Andrews, B.D., 2009. Size distribution of submarine landslides along the U.S. Atlantic Margin. Marine Geology 16-27.

Chaytor, J., Ten Brink, U., Twichell, D., Baxter, C., Hallam, T., Brothers, D., 2011. Submarine landslides along the US Atlantic margin: their distribution, failure processes, and age. AGU Fall Meeting Abstracts, p. 2302.

Chaytor, J.D., Twichell, D., ten Brink, U.S., 2012a. Reevaluation of the Munson-NygrenRetriever submarine landslide complex, Georges Bank Lower Slope, Western North Atlantic. In: Yamada, et al. (Eds.), Submarine Mass Movements and their Consequences, Advances in Natural and Technological Hazards Research, vol. 31, pp. 131-145.

Chaytor, J.D., Brothers, D.S., Ten Brink, U.S., Baxter, C., 2012b. Submarine landslides on the Mid-Atlantic and Southern New England Continental Margins, USA. AGU Fall Meeting Abstract (OS43C-1828)

Churchill, D.D., Houston, S.H., Bond, N.A., 1995. The Daytona Beach Wave of 3-4 July 1992: a shallow-water gravity wave forced by a propagating squall line. Bulletin of the American Meteorological Society 76, 21-32.

Dalyander, P.S., Butman, B., Sherwood, C.R., Signell, R.P., Wilkin, J.L., 2013. Characterizing wave-and current-induced bottom shear stress: U.S. middle Atlantic continental shelf. Continental Shelf Research 53, 73-86.

Danforth, W.W., Schwab, W.C., 1990. High-resolution seismic stratigraphy of the upper continental rise seaward of Georges Bank, Miscellaneous Field Studies Map, 2111 ed, pp. 24 maps and 24 sections on 11 sheets;sheets $94 \times 138 \mathrm{~cm}$. and smaller, folded in envelope $132 \times 124 \mathrm{~cm}$. +131 pamphlet $(110$ p.; $128 \mathrm{~cm}$. $)$

Day, S., Heleno da Silva, S., Fonseca, J., 1999. A past giant lateral collapse and present-day flank instability of Fogo, Cape Verde Islands. Journal of Volcanology and Geotherma Research 94, 191-218.

DeMets, C., Gordon, R.G., Argus, D.F., 2010. Geologically current plate motions. Geophysical Journal International 181, 1-80.

Densmore, A., Ellis, M., Anderson, R., 1998. Landsliding and the evolution of normal-faultbounded mountains. Journal of Geophysical Research 103, 15203-15219.

Dillon, W.P., Popenoe, P., Grow, J.A., Klitgord, K.D., Swift, B.A., Paull, C.K., Cashman, K.V., 1982. Growth faulting and salt diapirism: their relationship and control in the Carolina Trough, Eastern North America: Rifted Margins. In: Watkins, J.S., Drake, C.L. (Eds.), Field Investigations of Margin Structure and Stratigraphy, 34. AAPG Memoir, pp. 21-46.

Dillon, W., Paull, C., Gilbert, L., 1985. History of the Atlantic continental margin off Florida: the Blake Plateau Basin. In: Poag, C.W. (Ed.), Geologic Evolution of the United States Atlantic Margin. Van Nostrand Reinhold, New York, pp. 189-215.

Dixon, T.H., Farina, F., DeMets, C., Jansma, P., Mann, P., Calais, E., 1998. Relative motion between the Caribbean and North American plates and related boundary zone deformation from a decade of GPS observations. Journal of Geophysical Research 103, 15157-15182.

Dolan, J.F., Wald, D.J., 1998. The 1943-1953 north-central Caribbean earthquakes: Active tectonic setting, seismic hazards, and implications for Caribbean-North America plate motions. Geological Society of America Special Publications 326, $143-170$.

Donn, W.L., Balachandran, N.K., 1969. Coupling between a moving air-pressure disturbance and the sea surface. Tellus 21, 701-706.

Donn, W.L., McGuinness, W.T., 1960. Air-coupled long waves in the ocean. Journal of Meteorology 17, 515-521.

Draper, G., Barros, J., 1994. Cuba (chapter 4). In: Donovan, S.K., Jackson, T.A. (Eds.), Caribbean Geology: An Introduction. UWIPA, Kingston, pp. 65-85.

Dugan, B., Fleming, P.B., 2000. Overpressure and fluid flow in the New Jersey continental slope: implications for slope failures and cold seeps. Science 289, 288-291.

Elmore, R.D., Pilkey, O.H., Cleary, W.J., Curran, H.A., 1979. Black Shell turbidite, Hatteras Abyssal Plain, western Atlantic Ocean. Geological Society of America Bulletin 90, 1165-1176.

Elverhøi, A., Breien, H., Blasio, F., Harbitz, C., Pagliardi, M., 2010. Submarine landslides and the importance of the initial sediment composition for run-out length and final deposit. Ocean Dynamics 60, 1027-1046.

Embley, R.W., 1980. The role of mass transport in the distribution and character of deepocean sediments with special reference to the North Atlantic. Marine Geology 38, 23-50.

Embley, R.W., 1982. Anatomy of some Atlantic margin sediment slides and some comments on ages and mechanisms. In: Saxov, S., Neiuwenhuis, J.K. (Eds.), Marine Slides and other Mass Movements. Springer, pp. 189-213.

Embley, R.W., Jacobi, R.D., 1977. Distribution and morphology of large submarine sediment slides and slumps on Atlantic continental margins. Marine Georesources \& Geotechnology 2, 205-228.
Enet, F., Grilli, S.T., 2007. Experimental study of tsunami generation by three-dimensional rigid underwater landslides. Journal of Waterway, Port, Coastal and Ocean Engineering $133,442-454$.

Ewing, M., Press, F., Donn, W.L., 1954. An Explanation of the Lake Michigan Wave of 26 June 1954. Science 120, 684-686.

Fader, G.B., 1991. Gas-related sedimentary features from the eastern Canadian continental shelf. Continental Shelf Research 11, 1123-1153.

Fine, I.V., Rabinovich, A.B., Bornhold, B.D., Thomson, R.E., Kulikov, E.A., 2005. The Grand Banks landslide-generated tsunami of November 18, 1929; preliminary analysis and numerical modeling. Marine Geology 45-57.

Flemings, P.B., Liu, X., Winters, W.J., 2003. Critical pressure and multiphase flow in Blake Ridge gas hydrates. Geology 31, 1057-1060.

Flemings, P., Long, H., Dugan, B., Germaine, J., John, C., Behrmann, J.H., Sawyer, D., Expedition, I., 2008. Pore pressure penetrometers document high overpressure near the seafloor where multiple submarine landslides have occurred on the continental slope, offshore Louisiana, Gulf of Mexico. Earth and Planetary Science Letters 269, 309-325.

Frankel, A.D., Mueller, C.S., Barnhard, T.P., Perkins, D.M., Leyendecker, E.V., Dickman, N. Hanson, S.L., Hopper, M.G., 1996. National seismic-hazard maps; documentation June 1996. p. 110

Fukao, Y., 1973. Thrust faulting at a lithospheric plate boundary the Portugal earthquake of 1969. Earth and Planetary Science Letters 18, 205-216.

García, J., Slejko, D., Alvarez, L., Peruzza, L., Rebez, A., 2003. Seismic hazard maps for Cuba and surrounding areas. Bulletin of Seismological Society of America 93, 2563-2590.

Gee, M., Masson, D., Watts, A., Allen, P., 1999. The Saharan debris flow: an insight into the mechanics of long runout submarine debris flows. Sedimentology 46, 317-335.

Geist, E.L., 1999. Local tsunamis and earthquake source parameters. Advances in Geophysics 39, 117-209.

Geist, E.L., Parsons, T., 2006. Probabilistic analysis of tsunami hazards. Natural Hazards 37, 277-314.

Geist, E.L., Parsons, T., 2009. Assessment of source probabilities for potential tsunamis affecting the U.S. Atlantic Coast. Marine Geology 264, 98-108.

Geist, E.L., ten Brink, U.S., 2012. NRC/USGS Workshop Report: Landslide Tsunami Probability. p. 635.

Geist, E.L., Lynett, P.J., Chaytor, J.D., 2009a. Hydrodynamic modeling of tsunamis from the Currituck landslide. Marine Geology 264, 41-52.

Geist, E.L., Parsons, T., ten Brink, U.S., Lee, H.J., 2009b. Tsunami probability. In: Bernard, E. N., Robinson, A.R. (Eds.), The Sea, 15. Harvard University Press, Cambridge Massachusetts, pp. 93-135.

Geist, E.L., Chaytor, J.D., Parsons, T., ten Brink, U., 2013. Estimation of submarine mass failure probability from a sequence of deposits with age dates. Geosphere 9, 287-298.

Georgiopoulou, A., Wynn, R.B., Masson, D.G., Frenz, M., 2009. Linked turbidite-debrite resulting from recent Sahara Slide headwall reactivation. Marine and Petroleum Geology 26, 2021-2031.

Georgiopoulou, A., Masson, D.G., Wynn, R.B., Krastel, S., 2010. Sahara Slide: age, initiation, and processes of a giant submarine slide. Geochemistry, Geophysics, Geosystems 11, Q07014. http://dx.doi.org/10.1029/2010GC003066.

Gisler, G., Weaver, R., Gittings, M.L., 2006. SAGE calculations of the tsunami threat from La Palma. Science of Tsunami Hazards 24, 288-301.

González, F.I., Geist, E.L., Jaffe, B.E., Kânoglu, U., Mofjeld, H.O., Synolakis, C.E., Titov, V.V., Arcas, D., Bellomo, D., Carlton, D., Horning, T.S., Johnson, J., Newman, J.C., Parsons, T. Peters, R., Peterson, C., Priest, G.R., Venturato, A.J., Weber, J., Wong, F., Yalciner, A.C., 2009. Probabilistic tsunami hazard assessment at Seaside, Oregon for near- and farfield seismic sources. Journal of Geophysical Research 114. http://dx.doi.org/10. 1029/2008JC005132.

Goodbred, S., Krentz, S., LoCicero, P., 2006. Evidence for a newly discovered 2300-year-old tsunami deposit from Long Island. AGU Fall, Meeting Abstracts, New York pp. OS43C-OS0681C.

Grilli, S.T., Watts, P., 2005. Tsunami generation by submarine mass failure. I: modeling experimental validation, and sensitivity analyses. Journal of Waterway, Port, Coasta and Ocean Engineering 131, 283-297.

Grilli, S., Dubosq, S., Pophet, N., Pérignon, Y., Kirby, J., Shi, F., 2010. Numerical simulation and first-order hazard analysis of large co-seismic tsunamis generated in the Puerto Rico trench: near-field impact on the North shore of Puerto Rico and far-field impact on the US East Coast. Natural Hazards and Earth System Sciences 10, 2109-2125.

Gutscher, M.-A., 2004. What caused the Great Lisbon earthquake? Science 305, 1247-1248.

Guzzetti, F., Malamud, B.D., Turcotte, D.L., Reichenbach, P., 2002. Power-law correlations of landslide areas in central Italy. Earth and Planetary Science Letters 195, 169-183.

Haflidason, H., Lien, R., Sejrup, H.P., Forsberg, C.F., Bryn, P., 2005. The dating and morphometry of the Storegga Slide. Marine and Petroleum Geology 22, 123-136.

Hampton, M.A., Lee, H.J., Locat, J., 1996. Submarine landslides. Reviews of Geophysics 34, 33-59.

Harbitz, C.B., Løvholt, F., Pedersen, G., Masson, D.G., 2006. Mechanisms of tsunami generation by submarine landslides: a short review. Norwegian Journal of Geology 86, 255-264

Harbitz, C.B., Løvholt, F., Bungum, H., 2013. Submarine landslide tsunamis: how extreme and how likely? Natural Hazards 1-34.

Haugen, K.B., Løvholt, F., Harbitz, C.B., 2005. Fundamental mechanisms for tsunami generation by submarine mass flows in idealised geometries. Marine and Petroleum Geology 22, 209-217.

Hildenbrand, A., Marques, F., Catalão, J., Catita, C., Costa, A., 2012. Large-scale active slump of the southeastern flank of Pico Island, Azores. Geology 40, 939-942.

Hornbach, M.J., Lavier, L.L., Ruppel, C.D., 2007. Triggering mechanism and tsunamigenic potential of the Cape Fear slide complex (G-cubed 8, Q12008, 12010.11029/ 12007GC001722.).

Hovius, N., Stark, C.P., Allen, P.A., 1997. Sediment flux from a mountain belt derived by landslide mapping. Geology 25, 231-234. 
Hunt, J.E., Wynn, R.B., Talling, P.J., Masson, D.G., 2013a. Multistage collapse of eight western Canary Island landslides in the last $1.5 \mathrm{Ma}$ : sedimentological and geochemical evidence from subunits in submarine flow deposits. Geochemistry, Geophysics, Geosystems 14, 2159-2181.

Hunt, J.E., Wynn, R.B., Talling, P.J., Masson, D.G., 2013b. Turbidite record of frequency and source of large volume $\left(>100 \mathrm{~km}^{3}\right)$ Canary Island landslides in the last $1.5 \mathrm{Ma}$ : implications for landslide triggers and geohazards. Geochemistry, Geophysics, Geosystems $14,2100-2123$.

Imran, J., Parker, G., Locat, J., Lee, H., 2001. A 1-D numerical model of muddy subaqueous and subaerial debris flows. Journal of Hydraulic Engineering 127, 959-968.

Ishii, M., Kiser, E., Geist, E.L., 2013. Mw 8.6 Sumatran earthquake of 11 April 2012: Rare seaward expression of oblique subduction. Geology 41, 319-322.

Johnston, A., 1996. Seismic moment assessment of earthquakes in stable continental regions - III New Madrid 1811-1812, Charleston 1886 and Lisbon 1755. Geophysical Journal International 126, 314-344.

Kajiura, K., 1963. The leading wave of a tsunami. Bulletin of the Earthquake Research Institute 41, 535-571.

Katz, O., Aharonov, E., 2006. Landslides in a vibrating sand-box: what controls types of slope-failure and frequency magnitude relations? Earth and Planetary Science Letters 247, 280-294.

Keefer, D.K., 1984. Landslides caused by earthquakes. Geological Society of America Bulletin 95, 406-421.

Klitgord, K.D., Behrendt, J.C., 1979. Basin structure of the US Atlantic margin. In: Watkins, J.S., Montadert, L., Dickerson, P.W. (Eds.), Geological and geophysical investigations of continental margins: American Association of Petroleum Geologists Memoir. The American Association of Petroleum Geologists, Tulsa, Oklahoma, pp. 85-112.

Klitgord, K.D., Hutchinson, D.R., Schouten, H., 1988. US Atlantic continental margin; structural and tectonic framework. In: Sheridan, R.E., Grow, J.A. (Eds.), The Geology of North America. Geological Society of America, Boulder, Colorado, pp. 19-55.

Knight, B., 2006. Model predictions of gulf and southern Atlantic coast tsunami impacts from a distribution of sources. Science of Tsunami Hazards 24, 304-312.

Korycansky, D.G., Lynett, P.J., 2005. Offshore breaking of impact tsunami: the Van Dorn effect revisited. Geophysical Research Letters 32. http://dx.doi.org/10.1029/ 2004GL021918.

Kozak, J.T., Moreira, V.S., Oldroyd, D.R., 2005. Iconography of the 1755 Lisbon Earthquake. Academy of Sciences of the Czech Republic, Prague (82 pp.)

Krastel, S., Wynn, R.B., Georgiopoulou, A., Geersen, J., Henrich, R., Meyer, M., Schwenk, T. 2012. Large-scale mass wasting on the Northwest African Continental Margin: some general implications for mass wasting on passive continental margins. In: Ikehara, K., Ogawa, Y., Urgeles, R., Mosher, D., Chaytor, J., Strasser, M., Yasuhiro Yamada, K.K. (Eds.), Submarine Mass Movements and Their Consequences. Springer, pp. 189-199.

Kvalstad, T.J., Andresen, L., Forsberg, C.F., Berg, K., Bryn, P., Wangen, M., 2005. The Storegga slide: evaluation of triggering sources and slide mechanics. Marine and Petroleum Geology 22, 245-256.

Laberg, J., Vorren, T., 2000. The Trænadjupet Slide, offshore Norway-morphology, evacuation and triggering mechanisms. Marine Geology 171, 95-114.

Le Bas, T., Masson, D.G., Holtom, R., Grevemeyer, I., 2007. Slope Failures of the Flanks of the Southern Cape Verde Islands, Submarine Mass Movements and Their Consequences. Springer pp. 337-345

Lee, H.J., 2009. Timing of occurrence of large submarine landslides on the Atlantic Ocean margin. Marine Geology 264, 53-64.

Lin, P., 2004. A numerical study of solitary wave interaction with rectangular obstacles. Coastal Engineering 51, 35-51.

Liu, P.L.-F., 2009. Tsunami modeling-propagation. In: Robinson, A.R., Bernard, E.N. (Eds.), The Sea. Harvard University Press, Cambridge, Massachusetts, pp. 295-319.

Locat, J., Lee, H., ten Brink, U., Twichell, D.C., Geist, E.L., Sansoucy, M., 2009. Geomorphology, stability and mobility of the Currituck slide. Marine Geology 264, 28-40.

Locat, J., ten Brink, U., Chaytor, J., 2010. The Block Composite Submarine Landslide, Southern New England Slope, USA: a morphological analysis. In: Lee, H.J., Urgeles, R., Mosher, D. C., R.C.S., Moscardelli, L., Chaytor, J.D., Baxter, C.D.P. (Eds.), Submarine Mass Movements and Their Consequences. Springer, pp. 267-277.

Locat, J., ten Brink, U.S., Chaytor, J.D., 2013. A geomorphological analysis of the Veatch slide complex off Massachusetts, U.S.A. Submarine mass movements and their consequences. Springer.

Lockridge, P.A., Whiteside, L.S., Lander, J.F., 2002. Tsunamis and tsunami-like waves of the eastern United States. Science of Tsunami Hazards 120-157.

López-Venegas, A.M., ten Brink, U.S., Geist, E.L., 2008. Submarine landslide as the source for the 1918 Mona Passage tsunami: observations and modeling. Marine Geology $254,35-46$.

Løvholt, F., Pedersen, G., Gisler, G., 2008. Oceanic propagation of a potential tsunami from the La Palma Island. Journal of Geophysical Research 113, C09026. http://dx.doi.org/ 10.1029/2007JC004603.

Lynett, P., 2008. Modeling of tsunami inundation. In: Lee, W.H.K. (Ed.), Encyclopedia of Complexity and System Science. Springer-Verlag.

Lynett, P., Liu, P.L.F., 2002. A numerical study of submarine-landslide-generated waves and run-up. Proceedings of the Royal Society of London A 458, 2885-2910.

Lynett, P.J., Liu, P.L.-F., 2005. A numerical study of run-up generated by three-dimensional landslides. Journal of Geophysical Research 10. http://dx.doi.org/10.1029/2004JC002443.

Mader, C.L., 2001. Modeling the La Palma landslide tsunami. Science of Tsunami Hazard $19,150-170$.

Malamud, B.D., Turcotte, D.L., 2006. An inverse cascade explanation for the power-law frequency-area statistics of earthquakes, landslides and wildfires. In: Cello, G. Malamud, B.D. (Eds.), Fractal Analysis for Natural Hazards. Geological Society, Special Publications, London, pp. 1-9.
Masaferro, J.L., Poblet, J., Bulnes, M., Eberli, G.P., Dixon, T.H., Mcclay, K.E.N., 1999. Palaeogene-Neogene/present day(?) growth folding in the Bahamian foreland of the Cuban fold and thrust belt. Journal of the Geological Society 156, 617-631.

Masson, D.G., Harbitz, C.B., Wynn, R.B., Pedersen, G., Løvholt, F., 2006. Submarine landslides: processes, triggers and hazard prediction. Philosophical Transactions of the Royal Society of London 364, 2009-2039.

Masson, D.G., Le Bas, T.P., Grevemeyer, I., Weinrebe, W., 2008. Flank collapse and largescale landsliding in the Cape Verde Islands, off West Africa. Geochemistry, Geophysics, Geosystems 9, Q07015.

Mazzotti, S., Adams, J., 2005. Rates and uncertainties on seismic moment and deformation in eastern Canada. Journal of Geophysical Research-Solid Earth 110, B09301.

McHugh, C.M., Ryan, W.B.F., Schreiber, B.C., 1993. The role of diagenesis in exfoliation of submarine canyons. American Association of Petroleum Geologists Bulletin 77, 145-172.

McHugh, C.M., Hartin, C.A., Mountain, G.S., Gould, H.M., 2010. The role of glacio-eustasy in sequence formation: mid-Atlantic Continental Margin, USA. Marine Geology 277, 31-47.

Meighan, H.E., ten Brink, U., Pulliam, J., 2013. Slab tears and intermediate-depth seismicity. Geophysical Research Letters 40,1-5. http://dx.doi.org/10.1002/grl.50830.

Micallef, A., Berndt, C., Masson, D.G., Stow, D.A.V., 2008. Scale invariant characteristics of the Storegga Slide and implications for large-scale submarine mass movements. Marine Geology 247, 46-60

Mienert, J., Vanneste, M., Bünz, S., Andreassen, K., Haflidason, H., Sejrup, H.P., 2005. Ocean warming and gas hydrate stability on the mid-Norwegian margin at the Storegga Slide. Marine and Petroleum Geology 22, 233-244.

Mitchell, N.C., 2003. Susceptibility of mid-ocean ridge volcanic islands and seamounts to large-scale landsliding. Journal of Geophysical Research 108, 2397.

Mitchell, N.C., Quartau, R., Madeira, J., 2012. Assessing landslide movements in volcanic islands using near-shore marine geophysical data: south Pico island, Azores. Bulletin of Volcanology 74, 483-496.

Monserrat, S., Vilibić, I., Rabinovich, A.B., 2006. Meteotsunamis: atmospherically induced destructive ocean waves in the tsunami frequency band. Natural Hazards and Earth System Sciences 6, 1035-1051.

Mosher, D.C., Piper, D.J.W., 2007. Analysis of multibeam seafloor imagery of the Laurentide Fan and the 1929 Grand Banks landslide area. In: Sakellariou, D., Locat, J., Lykousis, V. (Eds.), Submarine Mass Movements and Their Consequences. Springer, pp. $77-88$.

Mountain, G.S., Tucholke, B.E., 1985. Mesozoic and Cenozoic geology of the US Atlantic continental slope and rise. In: Poag, C.W. (Ed.), Geologic Evolution of the United States Atlantic Margin. Van Nostrand Reinhold, New York, pp. 293-341.

Mountain, G.S., Burger, R.L., Delius, H., Fulthorpe, C.S., Austin, J.A., Goldberg, D.S., Steckler, M.S., McHugh, C.M., Miller, K.G., Monteverde, D.H., 2007. The long-term stratigraphic record on continental margins. In: Nittrouer, C.A. (Ed.), Continental Margin Sedimentation: From Sediment Transport to Sequence Stratigraphy. Blackwell, Malden, pp. 381-458.

Muir-Wood, R., Mignan, A., 2009. A Phenomenological Reconstruction of the Mw9 November 1st 1755 Earthquake Source, The 1755 Lisbon Earthquake: Revisited. Springer pp. 121-146.

Mulder, T., Ducassou, E., Eberli, G., Hanquiez, V., Gonthier, E., Kindler, P., Principaud, M., Fournier, F., Léonide, P., Billeaud, I., 2012. New insights into the morphology and sedimentary processes along the western slope of Great Bahama Bank. Geology 40, 603-606.

Nocquet, J.-M., Calais, E., 2004. Geodetic measurements of crustal deformation in the Western Mediterranean and Europe. Pure and Applied Geophysics 161, 661-681.

O'Grady, D.B., Syvitski, J.P.M., Pratson, L.F., Sarg, J.F., 2000. Categorizing the morphologic variability of siliciclastic passive continental margins. Geology 28, 207-210.

Okal, E.A., Fritz, H.M., Synolakis, C.E., Borrero, J.C., Weiss, R., Lynett, P.J., Titov, V.V., Foteinis, S., Jaffe, B.E., Liu, P.L.-F., 2010. Field survey of the Samoa tsunami of 29 September 2009. Seismological Research Letters 81, 577-591.

O'Leary, D., 1986. The Munson-Nygren slide: a major lower-slope slide off Georges Bank. Marine Geology 72, 101-114.

Orange, D.L., Anderson, R.S., Breen, N.A., 1994. Regular canyon spacing in the submarine environment: the link between hydrology and geomorphology. GSA Today 4, 36-39.

Owen, M., Day, S., Maslin, M., 2007. Late Pleistocene submarine mass movements: occurrence and causes. Quaternary Science Reviews 26, 958-978.

Pasquet, S., Vilibić, I., 2013. Shelf edge reflection of atmospherically generated long ocean waves along the central U.S. East Coast. Continental Shelf Research 66, 1-8.

Pasquet, S., Vilibić, I., Šepić, J., 2013. A survey of strong high-frequency sea level oscillations along the US East Coast between 2006 and 2011. Natural Hazards and Earth System Sciences 13, 473-482.

Paull, C.K., Buelow, W.J., Ussler, W., Borowski, W.S., 1996. Increased continental-margin slumping frequency during sea-level lowstands above gas hydrate-bearing sediments. Geology 24, 143-146.

Person, M., Dugan, B., Swenson, J.B., Urbano, L., Stott, C., Taylor, J., Willett, M., 2003. Pleistocene hydrogeology of the Atlantic continental shelf, New England. Geological Society of America Bulletin 115, 1324-1343.

Phrampus, B.J., Hornbach, M.J., 2012. Recent changes to the Gulf Stream causing widespread gas hydrate destabilization. Nature 490, 527-530.

Piper, D.J.W., Cochonat, P., Morrison, M.L. 1999. The sequence of events around the epicentre of the 1929 Grand Banks earthquake: initiation of debris flows and turbidity current inferred from sidescan sonar. Sedimentology 46, 79-97.

Poag, W.C., 1991. Rise and demise of the Bahama-Grand Banks gigaplatform, northern margin of the Jurassic proto-Atlantic seaway. Marine Geology 102, 63-130.

Poag, C.W., 1992. U.S. Middle Atlantic Continental Rise: provenance, dispersal, and deposition of Jurasic to Quaternary sediments. In: Poag, C.W., de Graciancsky, P.C. (Eds.), Geologic Evolution of Atlantic Continental Rises. Van Nostrand Reinhold, New York, pp. 100-156. 
Poag, C.W., Sevon, W.D., 1989. A record of Appalachian denudation in postrift Mesozoic and Cenozoic sedimentary deposits of the US middle Atlantic continental margin. Geomorphology 2, 119-157.

Pratson, L.F., Coakley, B.J., 1996. A model for the headward erosion of submarine canyons induced by downslope-eroding sediment flows. Geological Society of America Bulletin 108, 225-234.

Pratson, L.F., Ryan, W.B.F., Mountain, G.S., Twichell, D.C., 1994. Submarine-canyon initiation by downslope-eroding sediment flows-evidence in Late Cenozoic strata on the New-Jersey continental slope. Geological Society of America Bulletin 106, 395-412.

Prior, D.B., Doyle, E.H., Neurauter, T., 1986. The Currituck Slide, Mid-Atlantic continental slope; revisited. Marine Geology 73, 25-45.

Prior, D., Suhayda, J., Lu, N.-Z., Bornhold, B., Keller, G., Wiseman, W., Wright, L., Yang, Z.-S., 1989. Storm wave reactivation of a submarine landslide. Nature 341, 47-50.

Proudman, J., 1929. The effects on the sea of changes in atmospheric Pressure. Geophysical Journal International 2, 197-209.

Reid, H.F., 1914. The Lisbon earthquake of November 1, 1755. Bulletin of the Seismological Society of America 4, 53-80.

Rikitake, T., Aida, I., 1988. Tsunami hazard probability in Japan. Bulletin of Seismological Society of America 78, 1268-1278.

Robb, J.M., 1984. Spring sapping on the lower continental slope, offshore New Jersey. Geology 12, 278-282.

Rodriguez, N.M., Paull, C.K., 2000. 32. DATA REPORT: 14C dating of sediment of the uppermost Cape Fear slide plain: constraints on the timing of this massive submarine landslide. In: Paull, C.K., Matsumoto, R., Wallace, P.J., Dillon, W.P. (Eds.), Proceedings of the Ocean Drilling Program. Scientific Results. US Government Printing Office, Washington DC, pp. 325-332.

Rodriguez, C.E., Bommer, J.J., Chandler, R.J., 1999. Earthquake-induced landslides: 19801997. Soil Dynamics and Earthquake Engineering 18, 325-346.

Roger, J., Baptista, M.A., Mosher, D., Hébert, H., Sahal, A., 2010. Tsunami impact on Newfoundland, Canada, due to far-field generated tsunamis. Implications on hazard assessment. Proceedings of the 9th U.S. National and 10th Canadian Conference on Earthquake Engineering, pp. 2625-2630.

Ryan, W., Cita, M., Miller, E., Hanselman, D., Nesteroff, W., Hecker, B., Nibbelink, M., 1978. Bedrock geology in New England submarine canyons. Oceanologica Acta $1,233-254$.

Sallenger Jr., A.H., List, J.H., Gelfenbaum, G., Stumpf, R.P., Hansen, M., 1995. Large wave at Daytona Beach, Florida, explained as a squall-line surge. Journal of Coastal Research 1383-1388.

Satake, K., 2007. Tsunamis. In: Kanamori, H., Schubert, G. (Eds.), Treatise on Geophysics. Earthquake Seismology, vol. 4. Elsevier, pp. 483-511.

Saura, E., Vergés, J., Brown, D., Lukito, P., Soriano, S., Torrescusa, S., García, R., Sánchez, J.R., Sosa, C., Tenreyro, R., 2008. Structural and tectonic evolution of western Cuba fold and thrust belt. Tectonics 27, TC4002.

Schlee, J.S., 1973. Atlantic continental shelf and slope of the United States: sediment texture of the northeastern part. USGS Professional Paper 529-L.

Scholz, C.H., Cowie, P.A., 1990. Determination of total strain from faulting using slip measurements. Nature 346, 837-839.

Senior Seismic Hazard Analysis Committee (SSHAC), 1997. Recommendations for Probabilistic Seismic Hazard Analysis: Guidance on Uncertainty and Use of Experts. U.S. Nuclear Regulatory Commission p. 256.

Solheim, A., Berg, K., Forsberg, C., Bryn, P., 2005. The Storegga Slide complex: repetitive large scale sliding with similar cause and development. Marine and Petroleum Geology 22, 97-107.

Stark, C., Hovius, N., 2001. The characterization of landslide size distribution. Geophysical Research Letters 28, 1091-1094.

Stich, D., Martín, R., Morales, J., 2010. Moment tensor inversion for Iberia-Maghreb earthquakes 2005-2008. Tectonophysics 483, 390-398.

Sultan, N., Cochonat, P., Foucher, J.-P., Mienert, J., 2004. Effect of gas hydrate melting on seafloor slope instability. Marine Geology 213, 379-401.

Swafford, L., Stein, S., 2007. Limitations of the short earthquake record for seismicity and seismic hazard studies. In: Stein, S., Mazzotti, S. (Eds.), Continental Intraplate Earthquakes. Geological Society of America, Boulder, pp. 49-58. ten Brink, U.S., 2005. Vertical motions of the Puerto Rico Trench and their cause. Journal of Geophysical Research 110, B06404. http://dx.doi.org/10.1029/2004JB003459.

ten Brink, U.S., López-Venegas, A.M., 2012. Plate interaction in the NE Caribbean subduction zone from continuous GPS observations. Geophysical Research Letters 39.

ten Brink, U.S., Villaseñor, A., 2012. Caribbean plate tectonics from seismic tomography. AGU Fall Meeting, T33H-02.

ten Brink, U.S., Geist, E.L., Andrews, B.D., 2006a. Size distribution of submarine landslides and its implication to tsunami hazard in Puerto Rico. Geophysical Research Letters 33. http://dx.doi.org/10.1029/2006GL026125.

ten Brink, U.S., Geist, E.L., Lynett, P., Andrews, B., 2006b. Submarine slides north of Puerto Rico and their tsunami potential. In: Mercado, A., Liu, P.L.-F. (Eds.), Caribbean Tsunami Hazard. World Scientific, Singapore, pp. 67-90.

ten Brink, U.S., Barkan, R., Andrews, B.D., Chaytor, J.D., 2009a. Size distributions and failure initiation of submarine and subaerial landslides. Earth and Planetary Science Letters 287, 31-42.

ten Brink, U.S., Lee, H.J., Geist, E.L., Twichell, D., 2009b. Assessment of tsunami hazard to the US East Coast using relationships between submarine landslides and earthquakes. Marine Geology 264, 65-73.

ten Brink, U.S., Bakun, W.H., Flores, C.H., 2011. Historical perspective on seismic hazard to Hispaniola and the northeast Caribbean region. Journal of Geophysical Research 116.

ten Brink, U.S., Chaytor, J.D., Andrews, B.D., Brothers, D.S., Geist, E.L., 2012. Updated size distribution of submarine landslides along the U.S. Atlantic margin. AGU Fall Meeting Abstract, OS43C-1827.

Thomas, C., Blair, N., Alperin, M., DeMaster, D., Jahnke, R., Martens, C., Mayer, L., 2002. Organic carbon deposition on the North Carolina continental slope off Cape Hatteras (USA). Deep Sea Research Part II: Topical Studies in Oceanography 49, 4687-4709.

Tuttle, M.P., Ruffman, A., Anderson, T., Jeter, H., 2004. Distinguishing tsunami from storm deposits in eastern North America: the 1929 Grand Banks tsunami versus the 1991 Halloween storm. Seismological Research Letters 75, 117-131.

Twichell, D.C., Knebel, H.J., Folger, D.W., 1977. Delaware River: evidence for its former extension to Wilmington Submarine Canyon. Science 195, 483-485.

Twichell, D., Chaytor, J.D., ten Brink, U.S., Buczkowski, B., 2009. Morphology of late Quaternary submarine landslides along the U.S. Atlantic margin. Marine Geology 264, 4-15.

Urlaub, M., Talling, P.J., Masson, D.G., 2013. Timing and freuquency of large submarine landslides: Implications for understanding triggers and future geohazard. Quaternary Science Reviews 72, 63-82.

Urlaub, M., Zervos, A., Talling, P., Masson, D.G., Clayton, C., 2012. How do $2^{\circ}$ slopes fail in areas od slow seidmentation? A sensitivity study of the influence of accumulation rate and permeability on submarine slope stability. In: Yamada, Y., et al. (Eds.) Submarine Mass Movements and Their Consequences. Springer, pp. 277-287.

Vendeville, B.C., Jackson, M.P., 1992. The rise of diapirs during thin-skinned extension. Marine and Petroleum Geology 9, 331-354.

Vennell, R., 2010. Resonance and trapping of topographic transient ocean waves generated by a moving atmospheric disturbance. Journal of Fluid Mechanics 650, 427-442.

Vilibić, I., Horvath, K., Strelec Mahović, N., Monserrat, S., Marcos, M., Amores, Á., Fine, I., 2013. Atmospheric processes responsible for generation of the 2008 Boothbay meteotsunami. Natural Hazards 1-29.

Ward, S.N., 2001. Landslide tsunami. Journal of Geophysical Research 106.

Ward, S.N., Day, S., 2001. Cumbre Vieja Volcano-potential collapse and tsunami at La Palma, Canary Islands. Geophysical Research Letters 28, 3397-3400.

Wei, Y., Ten Brink, U., Atwater, B., 2010. Modeling of tsunamis and hurricanes as causes of the catastrophic overwash of Anegada, British Virgin Islands, between 1650 and 1800. AGU Fall Meeting Abstracts, pp. T53A-T1567A

Wu, T.Y., 1981. Long waves in ocean and coastal waters. Journal of the Engineering Mechanics Division, ASCE 107, 501-522.

Zhou, H., Moore, C., Wei, Y., Titov, V., 2011. A nested-grid Boussinesq-type approach to modelling dispersive propagation and runup of landslide-generated tsunamis. Natural Hazards and Earth System Sciences 11, 2677-2697.

Zitellini, N., Gràcia, E., Matias, L., Terrinha, P., Abreu, M., DeAlteriis, G., Henriet, J. Dañobeitia, J., Masson, D., Mulder, T., 2009. The quest for the Africa-Eurasia plate boundary west of the Strait of Gibraltar. Earth and Planetary Science Letters 280, 13-50. 